\title{
On the collections of Indo-Australian Spirobolida (Diplopoda) kept in the Zoological Museum of the Moscow State University, Russia.
}

\section{Some Rhinocricidae}

\section{O комлекщиях индо-австралийских Spirobolida (Diplopoda), храняшихся в Зоологическом музее Московского государственного университета (Россия). 3. Некоторые Rhinocricidae}

\author{
S.I. Golovatch ${ }^{1}$, J.-P. Mauriès ${ }^{2}$, N. Akkari ${ }^{3}$ \\ С.И. Головач ${ }^{1}$, Ж.-П. Морьес ${ }^{2}$, Н. Аккари
}

\footnotetext{
${ }^{1}$ Institute for Problems of Ecology and Evolution, Russian Academy of Sciences, Leninsky prospekt 33, Moscow 119071 Russia. E-mail: sgolovatch@yandex.ru

${ }^{1}$ Институт проблем экологии и эволюции РАН, Ленинский проспект, 33, Москва 119071 Россия.

${ }^{2}$ Muséum national d'Histoire naturelle, Département de Systématique et Evolution, 61 rue Buffon, F-75231 Paris Cedex 05, France.

${ }^{3}$ Naturhistorisches Museum Wien, Burgring 7, A-1010 Wien, Austria.
}

KEY WORDS: millipede, taxonomy, iconography, New Guinea, Fiji, Solomon Islands.

КЛЮЧЕВЫЕ СЛОВА: двупарноногие многоножки, таксономия, иконография, Новая Гвинея, Фиджи, Соломоновы острова.

ABSTRACT. Most of the material of the family Rhinocricidae, the largest in the entire order Spirobolida and very common and diverse in Australasia, is treated, being represented in the collections of the Moscow Museum from the southwestern Pacific by at least seven species in four genera: Propodobolus, Dinematocricus, Eurhinocricus, and Salpidobolus. All these species are described and illustrated, but most of their identifications are only provisional because rhinocricid taxonomy is still generally chaotic, especially confused in the region we consider here. The genus Eurhinocricus is new to the fauna of Fiji. Lectotype designation is made for E. saipanus Verhoeff, 1937 from Saipan (= Guam), Marianas, Micronesia.

How to cite this paper: Golovatch S.I., Mauriès J.P., Akkari N. 2021. On the collections of Indo-Australian Spirobolida (Diplopoda) kept in the Zoological Museum of the Moscow State University, Russia. 3. Some Rhinocricidae // Arthropoda Selecta. Vol.30. No.1. P.3-27. doi: 10.15298/arthsel.30.1.01

РЕЗЮМЕ. Обработано большинство материала по семейству Rhinocricidae, самому крупному во всем отряде Spirobolida и очень обычному и разнообразному в Австралазии. Оно представлено в коллекциях одного лишь московского музея из юговосточной части Тихого океана по крайней мере семью видами из четырех родов: Propodobolus, Dinematocricus, Eurhinocricus и Salpidobolus. Все эти виды описаны и снабжены иллюстрациями, но большинство из них определены лишь предварительно, потому что таксономия семейства хаотична вообще и особенно запутана в данном районе в частности. Род Eurhinocricus - новый для фауны Фиджи. Для вида E. saipanus Verhoeff, 1937 с острова Сайпан (= Гуам) (Марианские острова, Микронезия) выделен лектотип.

\section{Introduction}

This is the third contribution to the fauna of the millipede order Spirobolida of the southwestern Pacific based on the collections of the Zoological Museum of the Moscow State University (ZMUM), Russia. This time it treats most of the material belonging to the very large family Rhinocricidae. Our previous contributions dealt with some old or new Pachybolidae and Spirobolellidae from New Guinea and Australia [Golovatch et al., 2020a, b].

Most of the ZMUM samples were taken in 1976 and 1977 by Yuriy I. Chernov and Galina F. Kurcheva during two expeditions on board the research vessels "Kallisto" and "Dmitry Mendeleyev", respectively, to several islands and archipelagos in the southwestern Pacific. A few additional samples were very generously donated to the ZMUM collections by Dmitry Telnov, Riga, Latvia.

Considering the global catalogue by Marek et al. [2003] and several subsequent relevant papers [González-Sponga, 2005; Rodrigues et al., 2012, 2020; Shelley, 2014; Golovatch, 2014], the family Rhinocricidae presently comprises 543 nominal species and 23 subspecies placed in 27 genera and three subgenera. The family is the largest in Spirobolida and shows two major distribution areas: one in the Americas where its 
species range from northern Argentina (but absent from Chile!) in the south to the Caribbean and northern Mexico in the north. The second area is in the southwestern Pacific, including almost entire Indonesia, the Philippines, New Guinea, Micronesia, Melanesia, and eastern Australia [Marek et al., 2003]. The catalogue of the Indo-Pacific Spirobolida by Jeekel [2001] is still fully relevant as regards Rhinocricidae.

Pitz et al. [2010], using both morphological and molecular evidence, recovered the suborder Rhinocricidea and its sole constituent family Rhinocricidae as monophyletic, and sister to the remaining suborders Trigoniulidea and Spirobolidea. The family is characterized by $2+2$ supralabral setae, a week lateral groove at the anterodorsal margin of the collum, the anterior gonopod sternite a large triangular plate without lateral extensions, with each coxite forming a slight groove to conceal/support, albeit without wrapping, a simple, thin, largely flagelliform, elongate, and often bifurcated posterior gonopod. In addition, species of the family Rhinocricidae are among the spirobolidans that show scobinae, a peculiar pair of paramedian pits at the front margin of prozonae.

Only two of the seven Rhinocricidae species documented below could be securely identified because too many taxa remain inadequately known [Jeekel, 2001]. Of $170+$ species or subspecies from nine formal rhinocricid genera hitherto reported from Australasia, about half are completely dubious. Even the generic assignments of numerous taxa are often provisional, and several names are invalid [Jeekel, 2001]. Against this background, we are inclined to follow a cautious approach and refrain from definite species identifications. Instead we offer perhaps the first adequate iconography of southwestern Pacific Rhinocricidae to depict and describe the ZMUM collections in proper detail, as a first step towards understanding the diversity and taxonomy of this group. Only this approach could seriously clarify much of the still prevailing taxonomic mess in the family and order [Golovatch et al., 2020a, b].

\section{Material and methods}

All new material treated below is deposited in the ZMUM. Colour pictures were obtained with a Canon EOS 5D digital camera and stacked using Zerene Stacker software. Type material housed in the Museum of Natural History, Vienna (Naturhistorisches Museum in Wien, NHMW) is partly revised and documented for comparison with the material in the ZMUM. NHMW types were illustrated using a Nikon DS-Ri-2 camera mounted on a Nikon SMZ25 stereo microscope using NIS-Elements Microscope Imaging Software with an Extended Depth of Focus (EDF) patch.

Some original labels have been edited a little to add detail and read better.

The classification, however deficient, follows that of Jeekel [2001] and Minelli [2015], allowing for catalogue sections to largely be omitted as redundant.

\section{Taxonomic part}

\section{Family Rhinocricidae Genus Propodobolus Silvestri, 1897}

Type species: Rhinocricus quintiporus Attems, 1897, by original designation.

COMMENT. This is a relatively small genus of Rhinocricidae currently comprising only nine species or subspecies from New Guinea and several surrounding archipelagos (Moluccas, Bismarck and Solomons) [Jeekel, 2001]. Following Jeekel [2001], we consider the species with only four apical cones on each antenna (= tetraconocerate), a strong to hypertrophied sternum of the anterior gonopods devoid of a basally constricted central process, coupled with a simple and bifurcate posterior gonopod only terminally broadened into an obliquely truncate blade, as belonging to this genus.

\section{Propodobolus sp.} Figs 1-9.

MATERIAL. $2 \bigcirc^{7} O^{7}, 2$ 우 (ZMUM), Indonesia, West Papua Province, Onin Peninsula, 5-7 km N of Fak-Fak, S2 ${ }^{\circ} 53^{\prime}$, E132 $12^{\circ}$, $300-400 \mathrm{~m}$ a.s.1., primary lowland tropical rainforest on limestone, 25.IX.2010, D. Telnov leg.

DESCRIPTION. Body ca. 170-185 mm long, width or height of midbody segments $14-15 \mathrm{~mm}\left(\mathrm{O}^{7}\right.$, + ), with $54 \mathrm{p}+1 \mathrm{ap}+\mathrm{T}(+)$ or $56 \mathrm{p}+\mathrm{T}\left(\sigma^{7},+\right)$ segments. Colouration uniformly blackish to black-brown, antennae, legs, gonopods and telson dark red-brown, clypeus usually red (Figs 1-9). Mesozonae often mottled with small light spots, apparently these being sigilla translucent from beneath.

Body cylindrical, postcollum constriction very faint (Fig. 2). Head as usual, bare, with three small, but evident, central teeth at fore margin of, and a short, axial and distinct suture on, labrum, followed by a superficial, fine, axial, epicranial line, with ca. 7-8+7-8 labral and 2+2 supralabral setae. Eye patches suboval, large and blackish (Fig. 1), each composed of ca. 23-25 flat ommatidia arranged in 5-6 vertical rows (e.g., ca. $5+5+5+4+3+2$ ); interantennal isthmus ca. $2.5 \mathrm{x}$ diameter of eye patch (Fig. 2). Antennae short and clavate, curved anteroventrad, in situ stretchable laterally behind until caudal margin of collum; in length, antennomere $2>3$ $>4=5=6>1>7$; antenomeres $5-7$ clothed with particularly dense, but mostly short setae; $8^{\text {th }}$ with four small apical cones (Figs 1,2). Tegument bare, almost smooth, very finely leathery, mostly shining (Figs $1-5$ ). Collum broadly rounded and clearly bordered only anteriorly, sulcus being rather short; caudolateral surface very delicately, densely, longitudinally and irregularly striolate (Fig. 1). Segment/ring 2 with a conspicuously flattened and subvertically striolate anteroventral part to subtend collum. Midbody segments/rings devoid of evident sutures between zonae, very poorly constricted and sometimes even slightly rugulose only between meso- and metazonae; dorsum bare until ring 7 or 8 , following metazonae and, later, mesozonae sparsely, irregularly, mostly finely and longitudinally striate/striolate dorsally, striations often being rather vague and abbreviated both caudally and anteriorly, mostly being deeper on metazonae; mesozonae remaining smooth from about ozopore level down to a particularly densely, obliquely and irregularly striolate ventrolateral third, while metazonae striate across entire circumference, but increasingly clearly, more densely and regularly so ventrolaterally; prozonae particularly densely, con- 

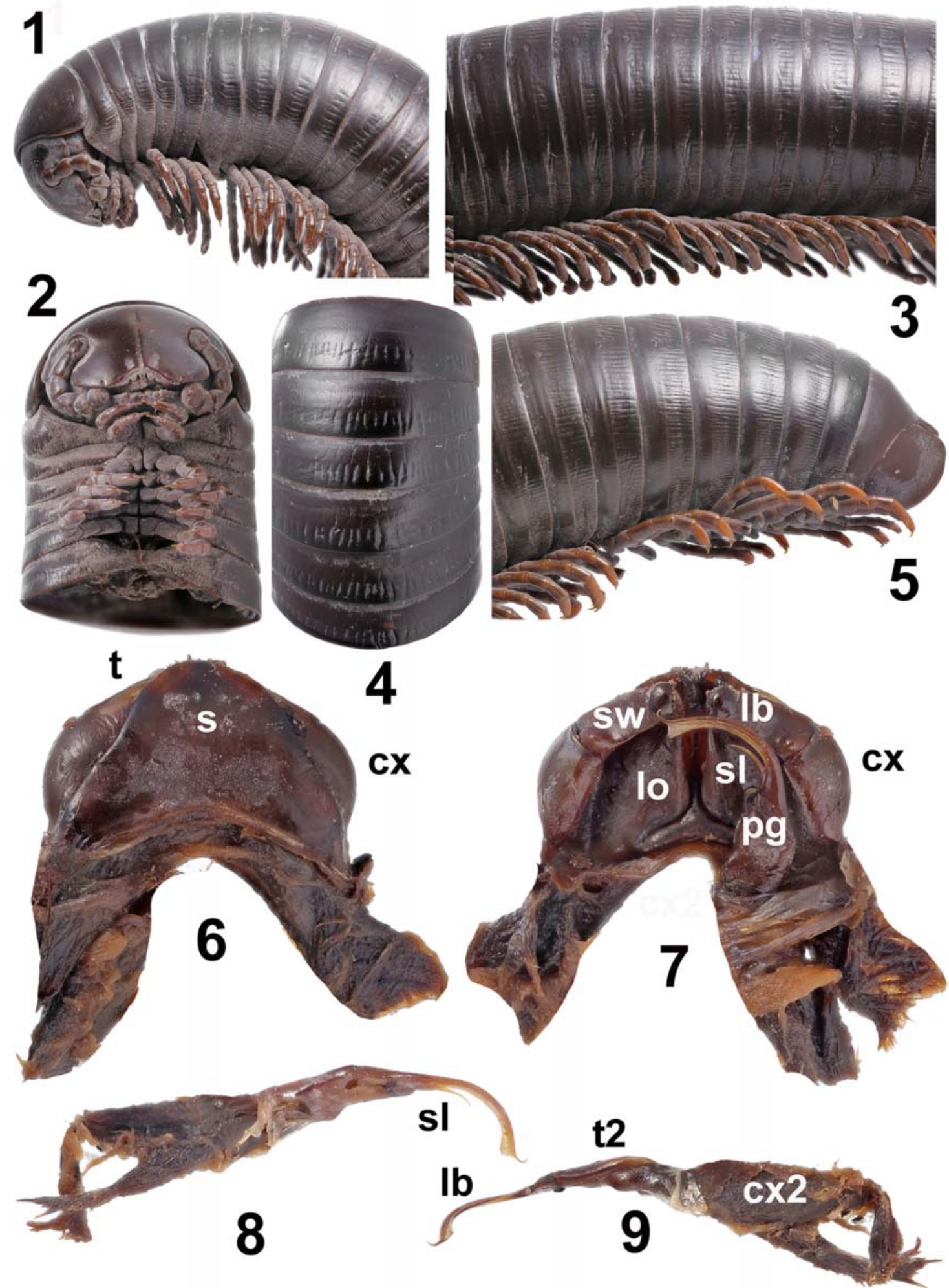

Figs 1-9. Propodobolus sp., $0^{\text {T }}$ from Onin Peninsula. 1, 2 - anterior part of body, lateral and ventral views, respectively; 3 - middle part of body, lateral view; 4 - body segments $8-13$, dorsal view; 5 - caudal part of body, lateral view; 6,7 - anterior gonopods and left posterior gonopod, anterior and posterior views, respectively; 8, 9- right posterior gonopod, anterior and posterior views, respectively. Designations explained in text. Pictures by K.V. Makarov, taken not to scale.

Pис. 1-9. Propodobolus sp., о с полуострова Онин. 1, 2 - передняя часть тела, соответственно сбоку и снизу; 3 - средняя часть тела, сбоку; 4 - туловищные сегменты 8-13, сверху; 5 - задняя часть тела, сбоку; 6,7 - передние гоноподы и левый задний гонопод, соответственно спереди и сзади; 8,9 - правый задний гонопод, соответственно спереди и сзади. Объяснения обозначений в тексте. Фотографии К.В. Макарова, сняты без масштаба. 
fusedly and vertically striolate (Figs $1-5$ ). Scobinae absent. Ozopores small and round disks lying at fore margin of metazonae on all leg-bearing segments starting with segment 6 (Figs 1, 3, 5). Telson (Fig. 5) as usual, epiproct flat, small, digitiform, clearly concave dorsally at base, rounded caudally; paraprocts very strongly and regularly convex, smooth, clearly bordered into prominent caudal lips with a conspicuous gutter between both valves; hypoproct nearly semi-circular, transverse, rounded caudally. Only $\sigma^{7}$ segment 7 clearly swollen ventrally, a complete ring due to a strong ventral bridge in caudal half (Figs 1, 2). No visible sigilla on internal surface of meso- and metazonae.

Legs short and slender, ca. $2 / 3$ as long as midbody height, each usually with a spine above and below claw, ventral spine being more clearly removed from claw; only $O^{3}$ legs 1 and 2 somewhat shorter and devoid of ventral sole pads on tarsi, while most following tarsi until those in $\sigma^{7}$ caudal body third with evident sole pads; $\sigma^{7}$ coxae 3-5 clearly expanded ventrally, rounded tubercles being more evident on coxae 3, but lower on coxae 5 (Fig. 2).

Gonopods strongly sclerotized (Figs 6-9). Anterior gonopods with an unusually prominent, high and semi-circular sternum (s) devoid of a median process, $\mathbf{s}$ being slightly higher than telopodites (t); the latter slender, each with a bulbous apical swelling (sw) on caudal face, only slightly longer than a stout coxa (cx) with its prominent, mesal, subtriangular process/lobe (lo); both lobes almost meeting at midline. Posterior gonopods (pg) connected with a simple, membranous, ribbon-shaped sternum, each gonopod consisting of a short subcylindrical coxa (cx2) and a slender, longer, bipartite telopodite (t2); apicolateral branch (lb) the largest, clearly curved, apically expanded into a small and obliquely truncate blade with a short, curved, apicolateral, flagelloid spike; mesal branch (= solenomere, sl) much shorter, flagelliform, originating just at base of $\mathbf{t} 2$.

REMARKS. This species readily resembles the particularly similar Propodobolus adipatus (Karsch, 1881) and $P$. beauforti (Attems, 1914), both nicely described and illustrated by Attems [1915] from Waigeo Island (formerly Waigeu), Raja Ampat Islands, Indonesia, and both showing rather irregular and vague striations on the metazonae, as well as hypertrophied and apically rounded sterna of the anterior gonopods. However, our species differs by the slightly higher sternum and apically non-pilose telopodites of the anterior gonopods. Moreover, $P$. adipatus and $P$. beauforti are so close both morphologically and geographically that they may well prove to represent different adult $\sigma^{7}$ developmental stadia of a single species. Gradual changes in gonopodal struncture have long been shown in the hemianamorphosis of Rhinocricidae [Mauriès, 1980; Enghoff et al., 1993; Bond et al., 2003]. So we are inclined instead to leave our sample unidentified closer.

In Propodobolus quintiporus (Attems, 1897) (the type species of the genus), P. compactilis (Attems, 1897), $P$. fulvescens (Carl, 1918), P. pachyskeles (Attems, 1897), and P. xanthopygus (Attems, 1897), all from the Moluccas, Indonesia [Attems, 1897; Carl, 1918], the anterior gonopod sternum is somewhat lower, sometimes bilobed apically, and the telopodites are clearly drawn apart either side of the midline.

The western, currently Indonesian part of New Guinea alone is also known to support a bunch of dubious rhinicrocids formally belonging to several genera, all of which Jeekel [2001] listed among Rhinocricidae, Spirobolida or even Juliformia of uncertain status. Two particularly enigmatic spe- cies, "Julus" roissyi Leguillou, 1841 and "Julus" doreyanus Gervais, 1847, come from New Guinea, the former taxon totally without a locality. Only the name of the latter species may represent a hint at Port Dorey, harbour of Manokwari, Doberai Peninsula, Indonesia.

In addition, "Rhinocricus" dimissus Silvestri, 1895 was described from "Andai". As all historic museum collections of the time also stem from near the settlement of Manokwari, $\mathrm{S} 0^{\circ} 55^{\prime}, \mathrm{E} 134^{\circ} 01^{\prime}$, the geographic provenance of that species seems to be clear. Likely the same concerns "Julus" roissyi as well. "Rhinocricus" granti Hirst, 1914 is known from near Mimika River, E136 30 30', S430', south of Mount Puncak Jaya, the highest peak of New Guinea, rather close to the town of Timika, Indonesia. "Dinematocricus" exul Chamberlin, 1920 is from "Djamna", the old name of Jamna Island, $\mathrm{S} 2^{\circ} 01, \mathrm{E} 139^{\circ} 15$, off the northern coast of New Guinea, between Sarmi and Javapura, Indonesia.

"Dinematocricus" fratrellus Chamberlin, 1920 and "D." permundus Chamberlin, 1920, are both from Manokwari again, the capital city of West Papua Province of Indonesia. Although no identified rhinocricid seems to have ever been recorded from the Onin Peninsula, because the risk of falling in synonymy seems to us too high, we refrain from labeling our Papuan Propodobolus species before at least some of the available type material of old dubious taxa becomes revised, and an iconography published. This would allow us to properly compare the types to our description and illustrations.

Propodobolus spp. share virtually the same, highly characteristic structure of the posterior gonopod not only with the genus Australocricus Jeekel, 2001, with seven species from eastern Australia [Jeekel, 2001], but also with some Eurhinocricus forms from the Antilles [Bond, Sierwald, 2002]. As this is likely to be evidence of a convergent evolution of that structure, the main distinction between the former two genera, both Australasian, remains the absence of a marked/high, basally constricted, central process on the anterior gonopod sternum in Propodobolus, vs. its presence in Australocricus.

\section{Genus Dinematocricus Brölemann, 1913}

Type species: D. lanceolatus Brölemann, 1913, by original designation.

COMMENT. This is one of the largest genera in Rhinocricidae currently comprising at least 44 nominal species or subspecies [Jeekel, 2001]. Following Jeekel [2001], we consider the species with only four apical cones on each antenna (= tetraconocerate), coupled with a simple, bifurcate and flagelliform posterior gonopod, as belonging to this genus. Contrary to Jeekel [2001], Hoffman [1974] considered it as a junior subjective synonym of Salpidobolus Silvestri, 1897 (see below).

Dinematocricus aff. bionus Chamberlin, 1920 Figs 10-31.

Dinematocricus bionus Chamberlin, 1920: 195, original description from the 9 holotype from Bio Island, Solomon Islands.

"Dinematocricus" bionus - Jeekel, 2001: 39.

MATERIAL. $1 \sigma^{\top}, 3$, 3 fragments (ZMUM), Solomon Islands, Isabel Province, Bio Island, S7 $31^{\prime} 49.3^{\prime \prime}, \mathrm{E} 158^{\circ} 41^{\prime} 0.1^{\prime \prime}$, on litter surface, 23.XII.1977, Yu.I. Chernov leg.

DESCRIPTION. The only complete specimen $\left(\sigma^{7}\right)$ ca. $85 \mathrm{~mm}$ long, $11.5 \mathrm{~mm}$ wide, with $32 \mathrm{p}+\mathrm{T}$ segments. $q$ fragments up to $11.5-12.0 \mathrm{~mm}$ wide. Colouration rather uni- 


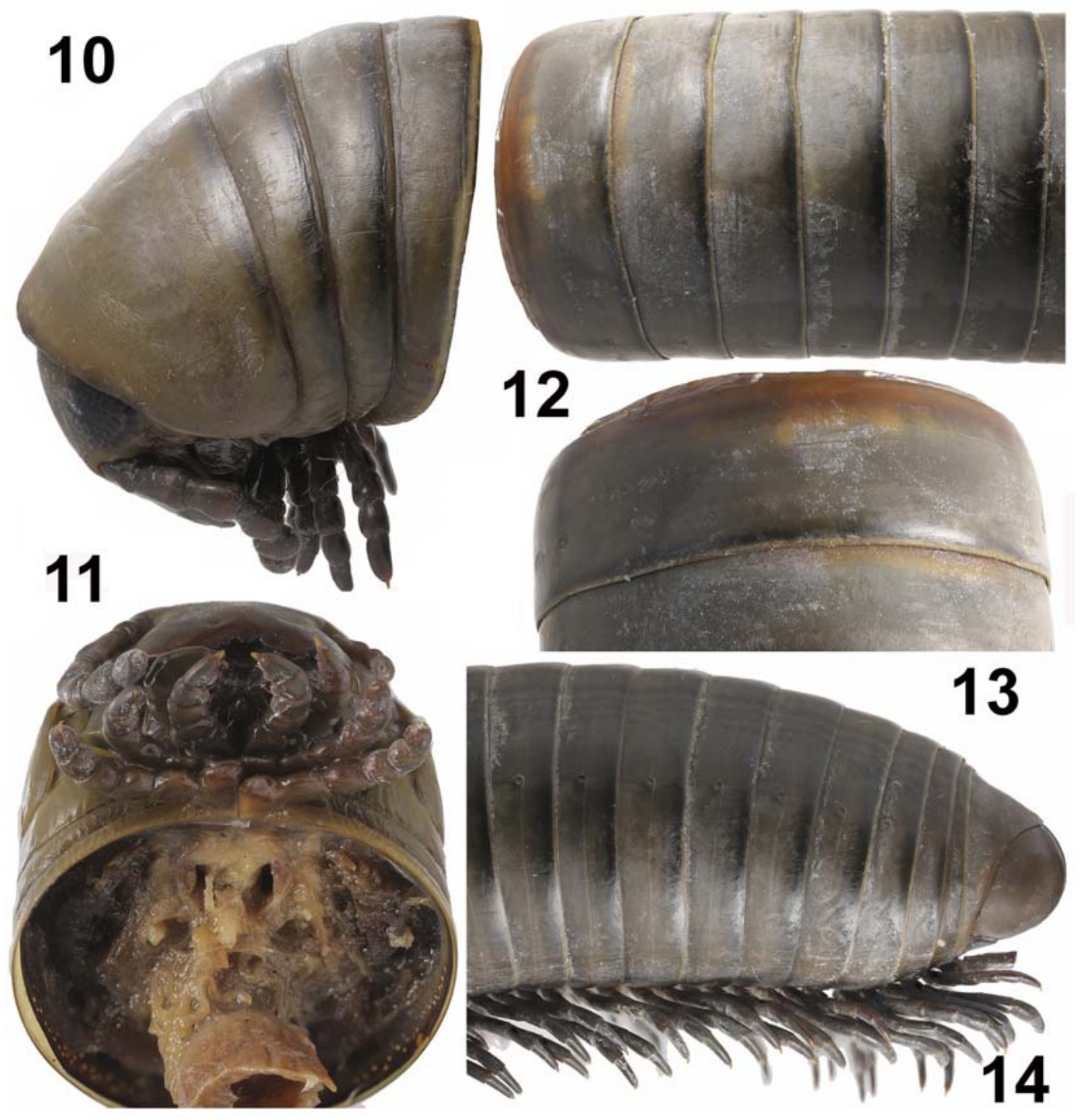

Figs 10-14. Dinematocricus aff. bionus Chamberlin, 1920, larger $\sigma^{7}$ from Bio Island. 10, 11 - anterior part of body, lateral and ventral views, respectively; 12 - middle part of body, dorsal view; 13 - midbody segment enlarged to show scobinae, dorsal view; 14 caudal part of body, lateral view. Pictures by K.V. Makarov, taken not to scale.

Рис. 10-14. Dinematocricus aff. bionus Chamberlin, 1920, более крупный ${ }^{7}$ с острова Био. 10, 11 - передняя часть тела, соответственно сбоку и снизу; 12 - средняя часть тела, сверху; 13 - увеличенный среднетуловищный сегмент со скобинами, сверху; 14 - задняя часть тела, сбоку. Фотографии К.В. Макарова, сняты без масштаба.

formly dark grey- to black-brown, mostly deep olive, only labrum and prozonae red-brown, legs grey- to reddish brown, and eye patches blackish (Figs 10-14).

All characters as in Propodobolus sp., except as follows.

Tegument smooth, finely leathery, mesozonae mostly shining, metazonae almost dull. Interantennal isthmus ca. $2 \mathrm{x}$ diameter of antennal socket. Collum broadly and regularly rounded laterally, anterior, lateral and even caudolateral margins clearly, but narrowly bordered. Midbody segments/ rings very faintly striolate, apparently strongly obliterate, more densely and clearly so ventrad, dorsum fully smooth; striolations on metazonae longitudinal and visible only in ventral $1 / 3$ (= well below ozopore level), on mesozonae slightly oblique, directed dorsad and extending up to ozopore level, but on both zonae still traceable even above ozopore (Figs 10-14), more clearly so and less strongly obliterate in $\bigcirc$ fragments. Scobinae present starting with ring 8: inconspicuous, paramedian, narrow, lunular pits separated from each other by their own width, devoid of posterior fields and placed just at anterior margin of prozona. Ozopores small, inconspicuous disks, starting with ring 6 , each pore lying upon line/suture both just before metazona and longitudinal line. Rather numerous light and irregular spots/ sigilla on internal surface of meso- and metazonae (Fig. 11).

Gonopods (Figs 15-18). Anterior gonopods with a very strong, long, median, spear-shaped, apically rounded, sternal process (s), the latter only slightly longer than both coxa (cx) and telopodite (t) with its small, apical, rounded, laterally directed process (tp); cx stout, with a strong, mesal, subtriangular, apically acuminate projection $(\mathbf{m p}), \mathbf{t}$ more slender than cx. Posterior gonopods consisting of a short, stout, subcylindrical coxa and a slender, much longer, bipar- 


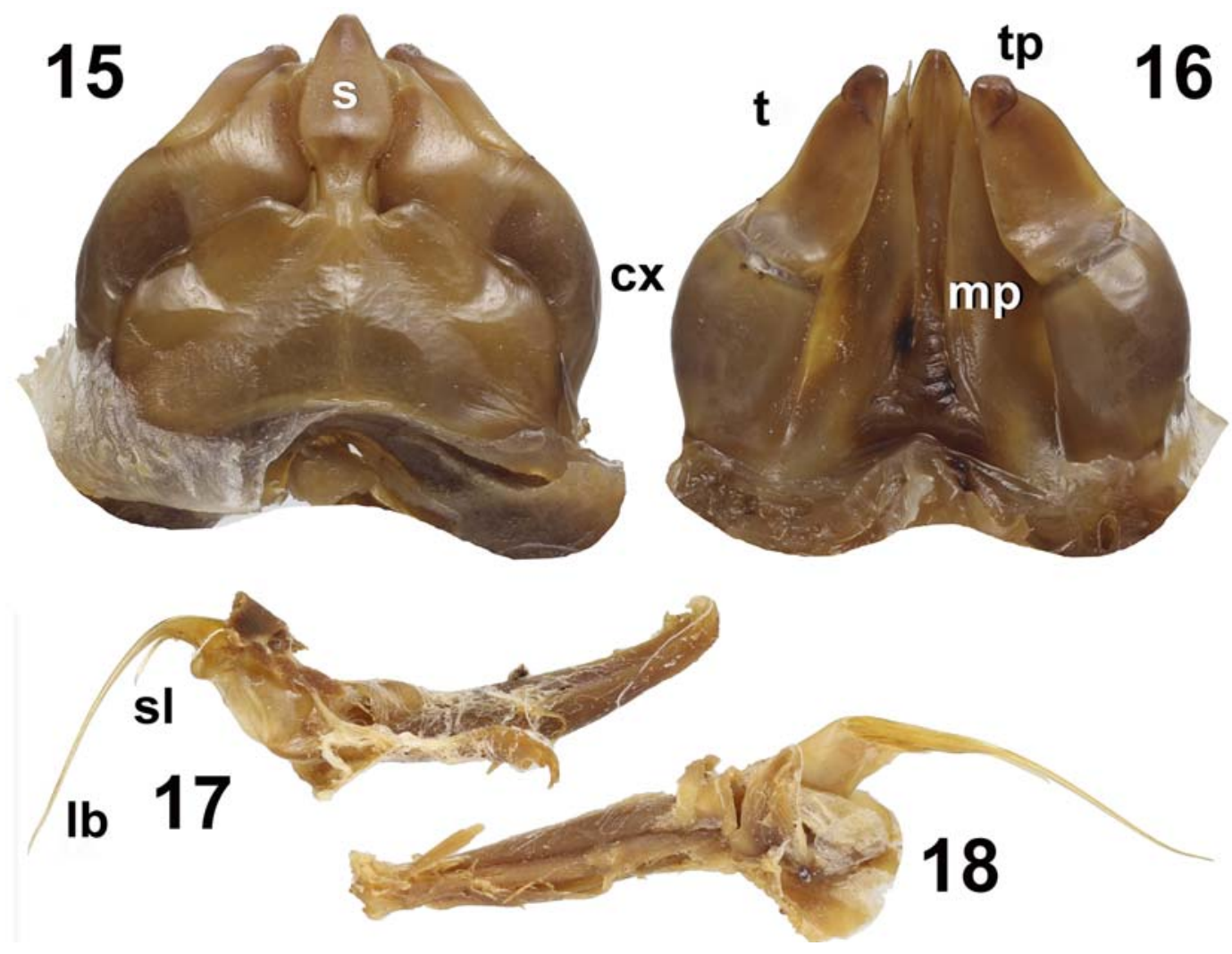

Figs 15-18. Dinematocricus aff. bionus Chamberlin, 1920, larger $0^{7}$ from Bio Island. 15, 16 - anterior gonopods, anterior and posterior views, respectively; 17, 18 - right posterior gonopod, anterior and posterior views, respectively. Designations explained in text. Pictures by K.V. Makarov, taken not to scale.

Рис. 15-18. Dinematocricus aff. bionus Chamberlin, 1920, более крупный $0^{7}$ с острова Био. 15, 16 - передние гоноподы, соответственно спереди и сзади; 17, 18 - правый задний гонопод, соответственно спереди и сзади. Объяснения обозначений в тексте. Фотографии К.В. Макарова, сняты без масштаба.

tite telopodite; apicolateral branch (lb) the longest, ca. 3x as long as a similarly flagelliform solenomere (sl).

REMARKS. According to Chamberlin [1920], the holotype of Dinematocricus bionus was ca. $145 \mathrm{~mm}$ in length and $11.5 \mathrm{~mm}$ in width, and the body with 60 segments. As nothing was said about the antennae, Jeekel [2001] assigned this species to Dinematocricus with but reservations, referring to the genus in quotation marks.

The original, purely verbal description of $D$. bionus disagrees with our account in a few, but quite important details. The holotype is much larger in length, but the same in width; the number of body segments is strikingly greater (obviously $59+\mathrm{T}, v s .32+\mathrm{T}$ ); the tegument is finely coriaceous and micropunctate (vs. coriaceous and impunctate); the scobinae are supplied with finely striolate, triangular, posterior fields ( $v s$. devoid of posterior fields); and the collum is narrowly rounded laterally (vs. broadly and regularly rounded).

The above strictly topotypic material from Bio Island in the ZMUM contains also $1 \sigma^{7}$ and $1 \%$ which are even smaller in size: length ca. $54 \mathrm{~mm}$, width $6 \mathrm{~mm}, 58+1+\mathrm{T}\left(\mathrm{O}^{7}\right)$

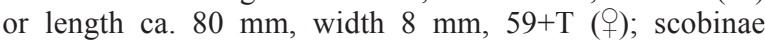
present on rings 8 to 31 . Both smaller specimens fully agree in every detail to the larger subsample described above, thus allowing all ZMUM material to be considered as likely conspecific. The smaller $\sigma^{T}$ and $q$ are only a little lighter than the larger ones, the striations on the body are less strongly obliterate and more clearly visible, while the gonopods are almost identical (Figs 19-31). Given the remarkable size variations, could the ZMUM material belong to the same species D. bionus? We tend to answer positively. The main type of anamorphosis in Spirobolida being hemianamorphosis, very considerable size variations in adult conspecific Rhinocricidae have long been noted, while the gonopods grow gradually and either remain unchanged or get at least somewhat modified from one stadium to the next [Mauriès, 1980; Enghoff et al., 1993; Bond et al., 2003]. The above variations in D. bionus seem best to be accounted for by hemianamorphosis.

However, before the holotype of D. bionus is properly revised, we refrain from definitely labeling our samples.

In addition to D. bionus, there are at least a few other congeners, e.g. D. carinatus (Karsch, 1881), D. lanceolatus Brölemann, 1913, D. repandus Attems, 1914 and D. strobilus Attems, 1914, in which the anterior gonopods show a similarly conspicuous and spear-shaped central sternal process [Brölemann, 1913; Attems, 1914], all of them from New Guinea and/or adjacent archipelagos [Jeekel, 2001]. Thus, a syntype of $D$. repandus is illustrated here to show the remarkable similarities to $D$. bionus in gonopodal structure (Figs 32-35). Another sample that clearly belongs to the same species group and identified as D. philistus Attems, 1914 is available in the ZMUM collections, as follows. 

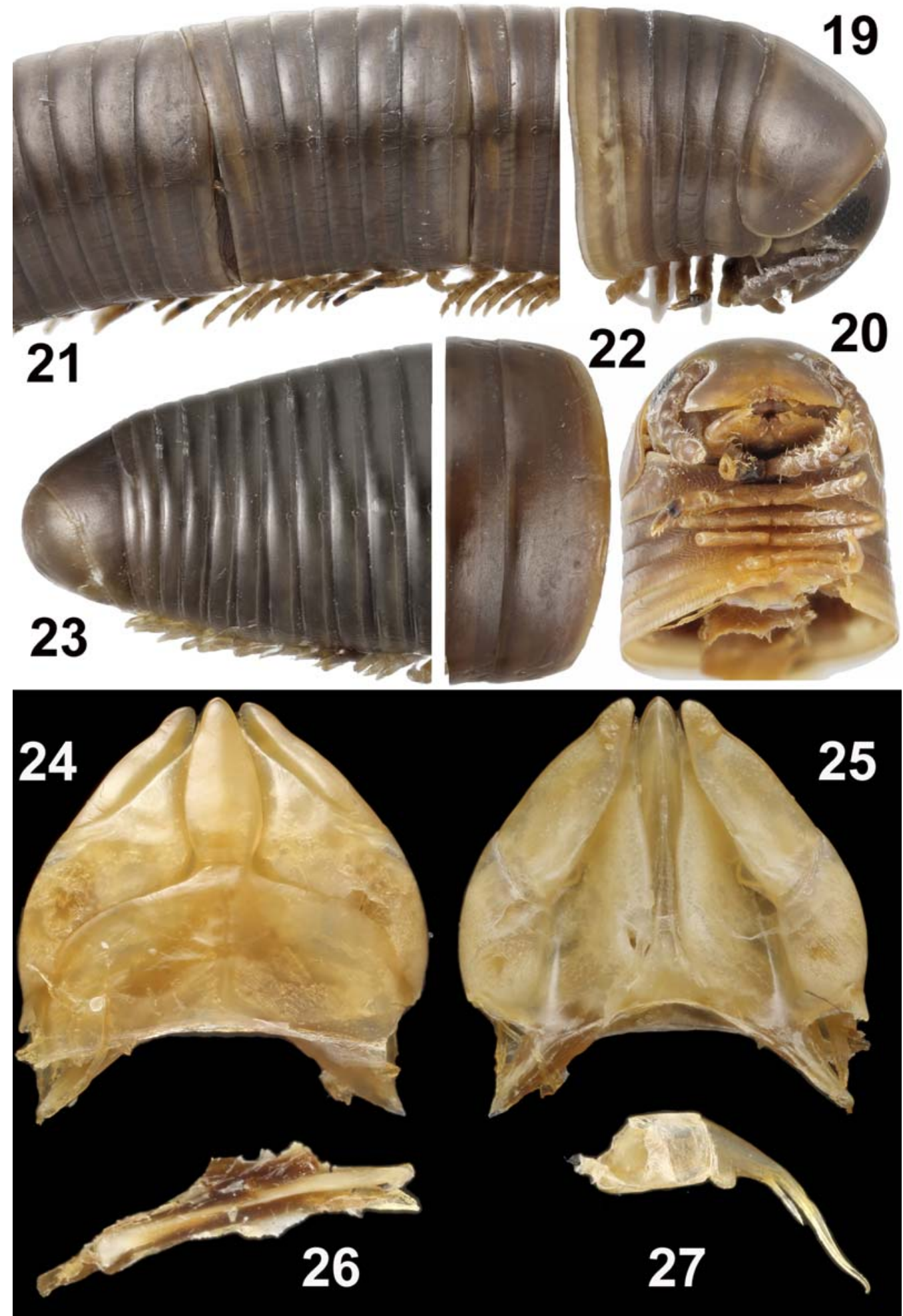

Figs 19-27. Dinematocricus aff. bionus Chamberlin, 1920, smaller $0^{7}$ from Bio Island. 19, 20 - anterior part of body, lateral and ventral views, respectively; 21 - middle part of body, lateral view; 22 - midbody segment enlarged to show scobinae, dorsal view; 23 caudal part of body, lateral view; 24, 25 - anterior gonopods, anterior and posterior views, respectively; 26, 27 - left posterior gonopod, anterior and posterior views, respectively. Designations explained in text. Pictures by K.V. Makarov, taken not to scale.

Рис. 19-27. Dinematocricus aff. bionus Chamberlin, 1920, более мелкий о с острова Био. 19, 20 - передняя часть тела, соответственно сбоку и снизу; 21 - средняя часть тела, сверху; 22 - увеличенный среднетуловищный сегмент со скобинами, сверху; 23 - задняя часть тела, сбоку; 24, 25 - передние гоноподы, соответственно спереди и сзади; 26,27 - левый задний гонопод, соответственно спереди и сзади. Объяснения обозначений в тексте. Фотографии К.В. Макарова, сняты без масштаба. 

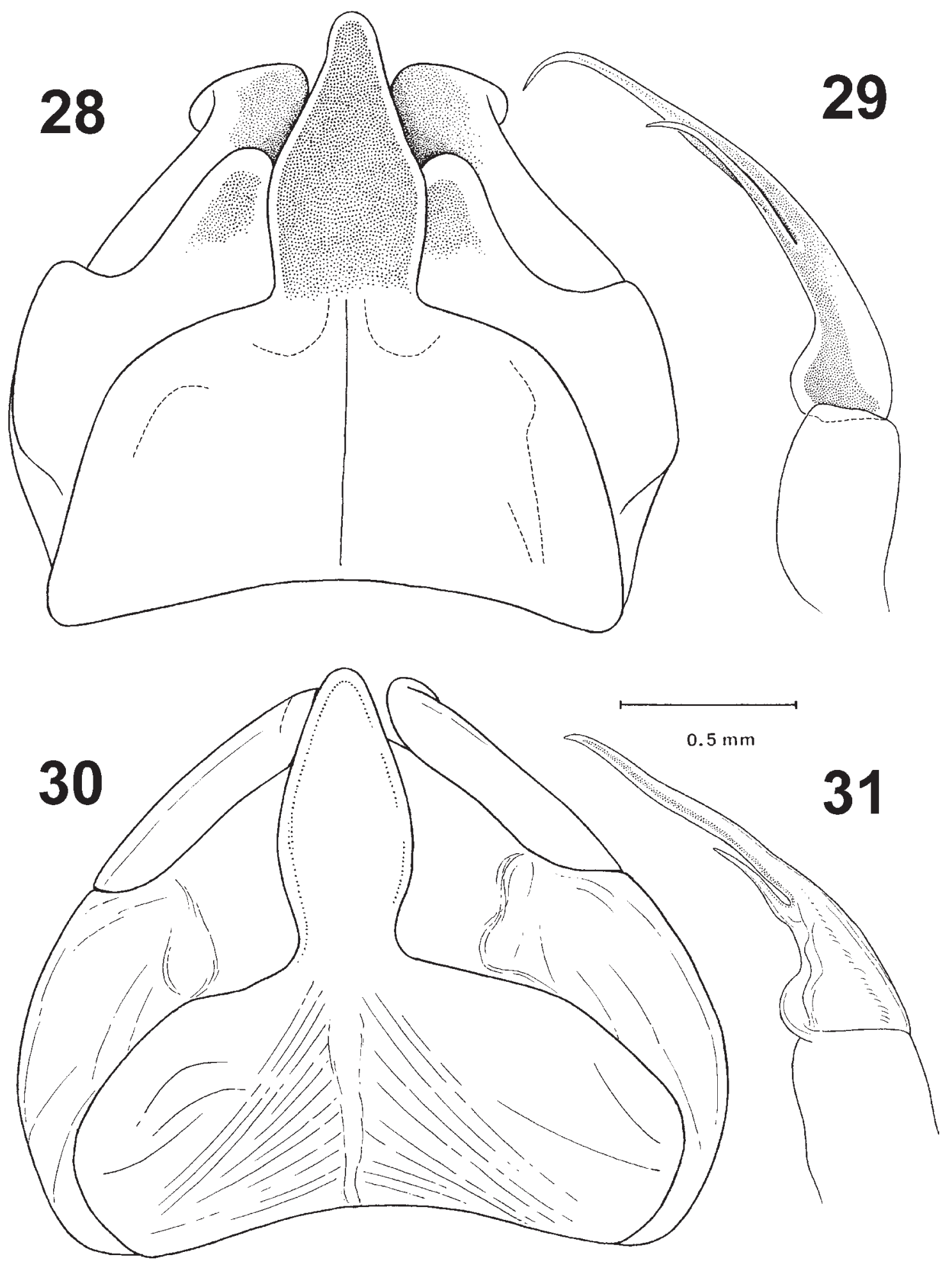

Figs 28-31. Dinematocricus aff. bionus Chamberlin, 1920, larger $(28,29)$ and smaller $(30,31) 0^{7} 0^{7}$ from Bio Island. $28,30-$ anterior gonopods, anterior view; 29, 31 - right posterior gonopod, posterior view.

Рис. 28-31. Dinematocricus aff. bionus Chamberlin, 1920 , более крупный $(28,29)$ и более мелкий $(30,31) 0^{7} 0^{7}$ с острова Био. 28 , 30 - передние гоноподы, спереди; 29, 31 - правый задний гонопод, сзади. 


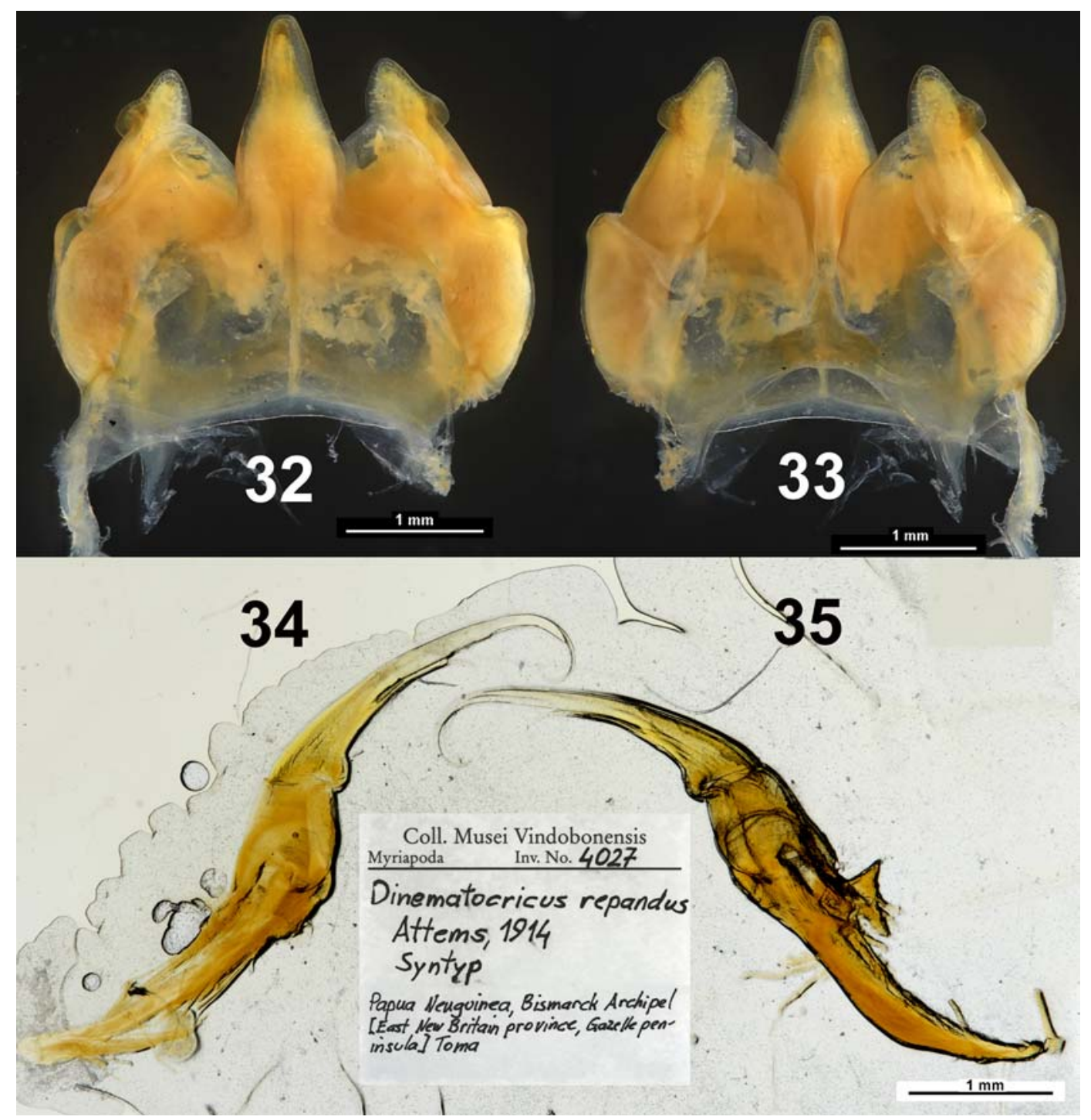

Figs 32-35. Dinematocricus repandus Attems, 1914, $0^{7}$ syntype from Gazelle Peninsula, East New Britain Province, Bismarck Archipelago, Papua New Guinea; slide NHMW 4027. 32, 33 - anterior gonopods, anterior and posterior views, respectively; 34, 35 both posterior gonopods, mesal and lateral views, respectively. Scale bars: $1.0 \mathrm{~mm}$.

Pис. 32-35. Dinematocricus repandus Attems, 1914, синтип О7 из Gazelle Peninsula, East New Britain Province, Bismarck Archipelago, Papua New Guinea; микропрепарат NHMW 4027. 32, 33 - передние гоноподы, соответственно спереди и сзади; 34, 35 - оба задних гонопода, соответственно изнутри и сбоку. Масштаб: 1,0 мм.

Dinematocricus philistus Attems, 1914

Figs 36-41.

Dinematocricus philistus Attems, 1914: 322, a brief original description in a key couplet; several syntypes from Seram and Ambon islands, Moluccas, Indonesia.

Dinematocricus philistus - Attems, 1915: 11, a detailed and illustrated description [Attems, 1915].

MATERIAL: 1 \% (ZMUM), eastern Indonesia, Maluku Tengah Prov., Molucca (= Maluku) Islands, northern Seram (formerly Ceram) Island, near Horale (Saka) village, S02 $56^{\prime} 15^{\prime \prime}, \mathrm{E} 129^{\circ} 04^{\prime} 54^{\prime \prime}$, shrubs and secondary lowland tropical forest, on road, 6.IV.2009, M. Kalniņš \& P. Pipkalēja leg.; 1 ㅇ (ZMUM), Central Moluccas Province (= Maluku Tengah), Lease Islands S of Seram, Saparua Island, $1.5 \mathrm{~km}$ NE of Kota Saparua, S03 $33^{\prime} 31^{\prime \prime}$, E128 $39^{\prime} 50^{\prime \prime}$, secondary lowland tropical forest, 10.IV.2009, M. Kalninšs leg.
DESCRIPTION. Topotype $\sigma^{7}$ from Seram ca. $80 \mathrm{~mm}$ long, $6.0 \mathrm{~mm}$ wide, with $53 \mathrm{p}+\mathrm{T}$ segments. + ca. $82 \mathrm{~mm}$ long, $10.0 \mathrm{~mm}$ wide, with $57 \mathrm{p}+\mathrm{T}$ segments. Colouration uniformly blackish to blackish brown; collum narrowly dark reddish along both anterior and caudal margins, following metazonae narrowly cingulate, similarly vague and dark reddish at caudal margin; prozonae often with yellow spots around/near scobinae; legs grey- or red-brown; labrum, antennae and most of telson dark brown, eye patches blackish (Figs 36-38).

All characters as in Propodobolus sp., except as follows.

Tegument smooth and shining, mostly very delicately incised. Epicranial suture short and fully or almost fully obliterate. Antennae very short and stout, only antennomeres 5-7 densely setose (Figs 36, 37). 

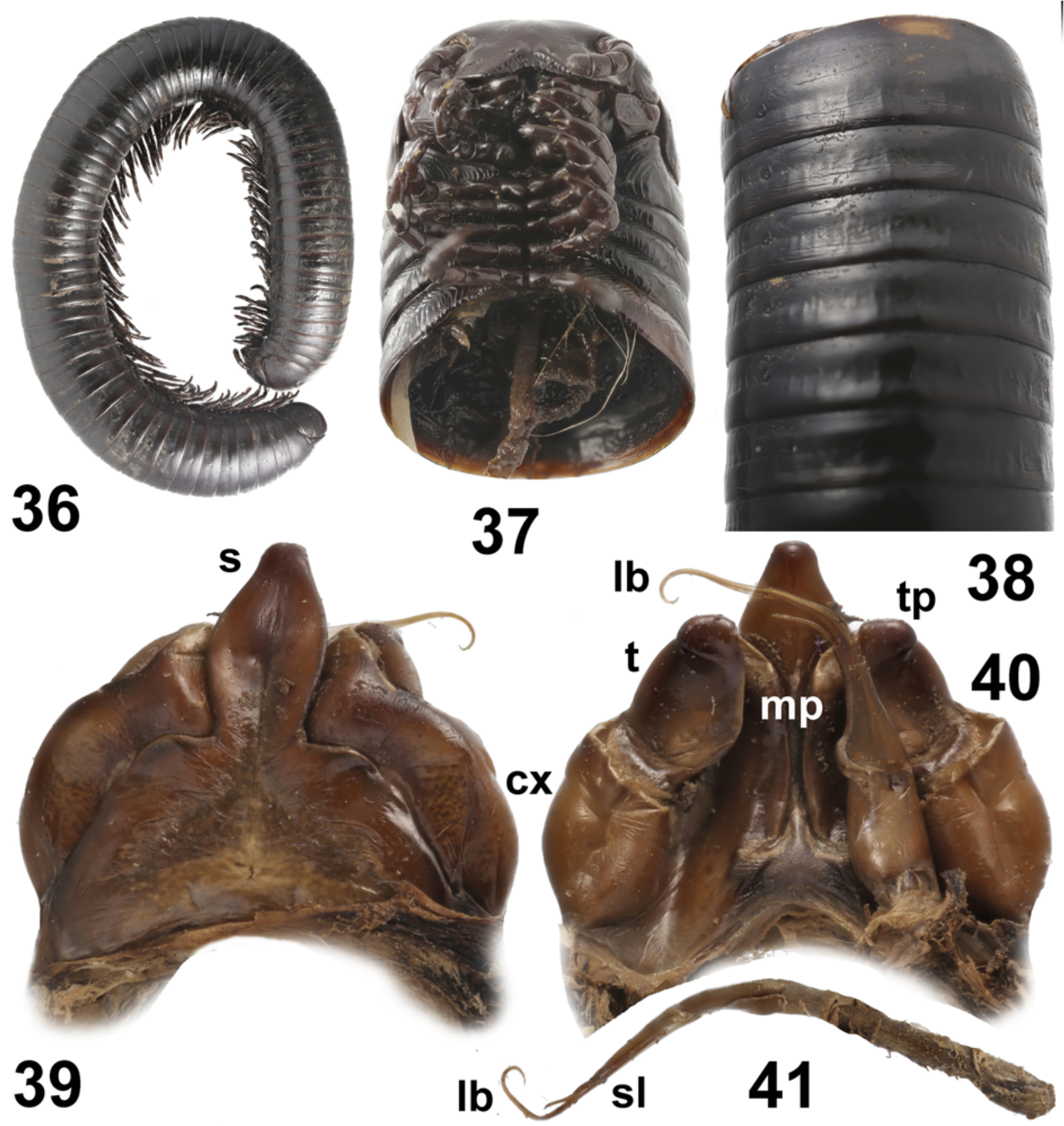

Figs 36-41. Dinematocricus philistus Attems, 1914, O $^{7}$ from Seram. 36 - habitus, lateral view; 37 - anterior part of body, ventral view; 38 - body segments 9-15, dorsal view; 39, 40 - both anterior gonopods and left posterior gonopod, anterior and posterior views, respectively; 41 - isolated right posterior gonopod, posterior view. Designations explained in text. Pictures by K.V. Makarov, taken not to scale.

Рис. 36-41. Dinematocricus philistus Attems, 1914, о7 с острова Серам. 36 - общий вид, сбоку; 37 - передняя часть тела, снизу; 38 - сегменты тела 9-15, сверху; 39, 40 - оба передних гонопода и левый задний гонопод, соответственно спереди и сзади; 41 - изолированный правый задний гонопод, сзади. Объяснения обозначений в тексте. Фотографии К.В. Макарова, сняты без масштаба.

Interantennal isthmus ca. $2 \mathrm{x}$ diameter of antennal socket. Collum broadly and regularly rounded laterally, anterior and lateral margins clearly, but narrowly bordered (Fig. 36). Midbody segments/rings faintly striate to striolate, more densely and clearly so ventrad, striations on dorsum above ozopore level being strongly obliterate, often abbreviated, but visible (Figs 36-38). Scobinae present, starting with ring 8 and traceable at least until midbody segments: inconspicuous, paramedian, narrow, lunular pits separated from each other by ca. $1.3 \mathrm{x}$ their own width, devoid of posterior fields and placed just at anterior margin of prozona (Fig. 38). Ozopores small, inconspicuous disks, starting with ring 6 , each pore lying upon line/suture both just before metazona and below longitudinal line. Rather numerous light and 


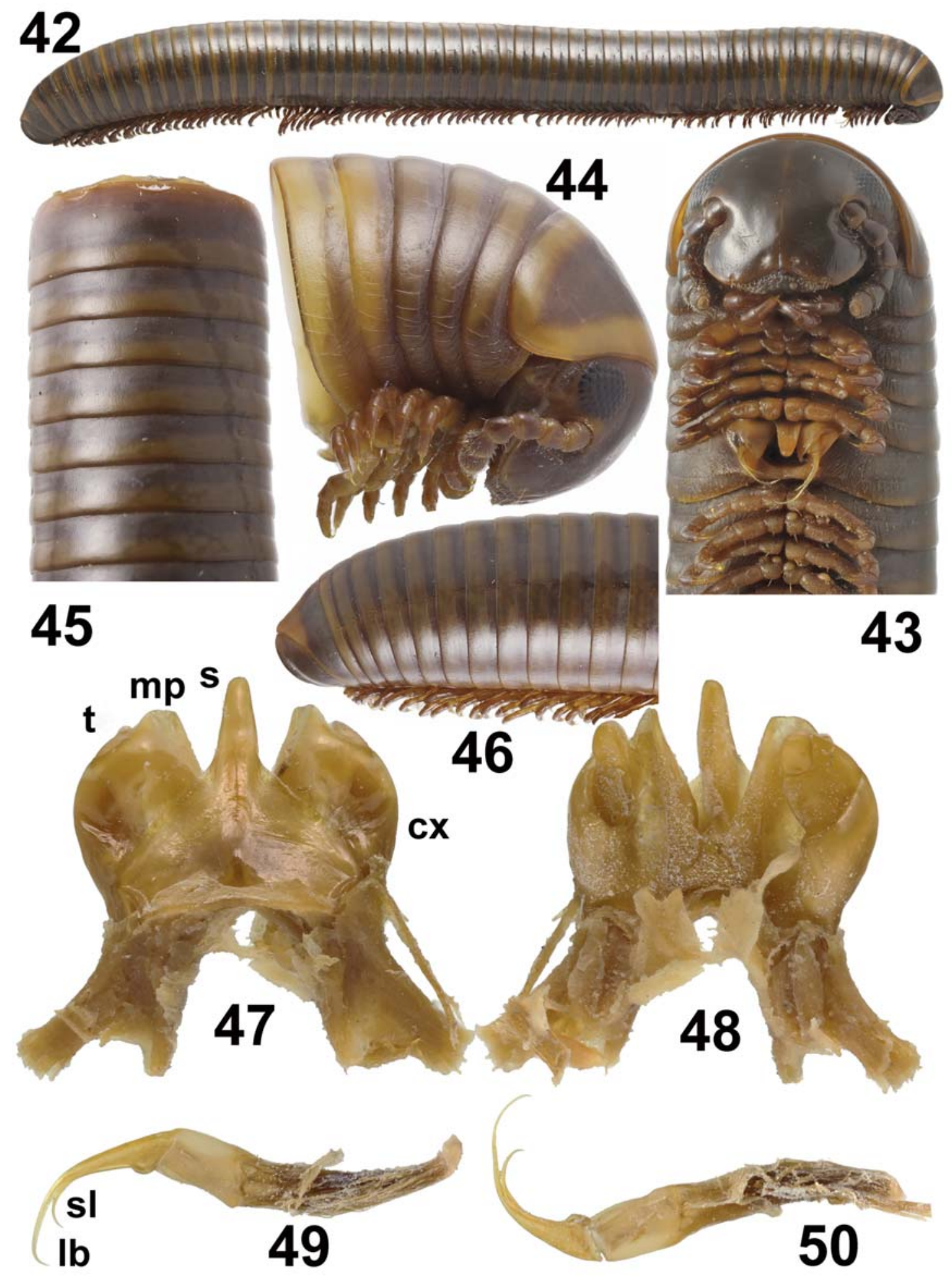

Figs 42-50. Dinematocricus aff. disjunctus Brölemann, 1913, $\sigma^{7}$ from Maclay Coast. 42 - habitus, lateral view; 43,44 - anterior part of body, ventral and lateral views, respectively; 45 - body segments 9-14, dorsal view; 46 - posterior part of body, lateral view; 47 , 48 - anterior gonopods, anterior and posterior views, respectively; 49, 50 - isolated left posterior gonopod, anterior and posterior views, respectively. Designations explained in text. Pictures by K.V. Makarov, taken not to scale.

Рис. 42-50. Dinematocricus aff. disjunctus Brölemann, 1913, О7 с Берега Маклая. 42 - общий вид, сбоку; 43,44 - передняя часть тела, соответственно снизу и сбоку; 45 - сегменты тела 9-14, сверху; 46 - задняя часть тела, сбоку; 47,48 - передние гоноподы, соответственно спереди и сзади; 49,50 - изолированный левый задний гонопод, соответственно спереди и сзади. Объяснения обозначений в тексте. Фотографии К.В. Макарова, сняты без масштаба. 


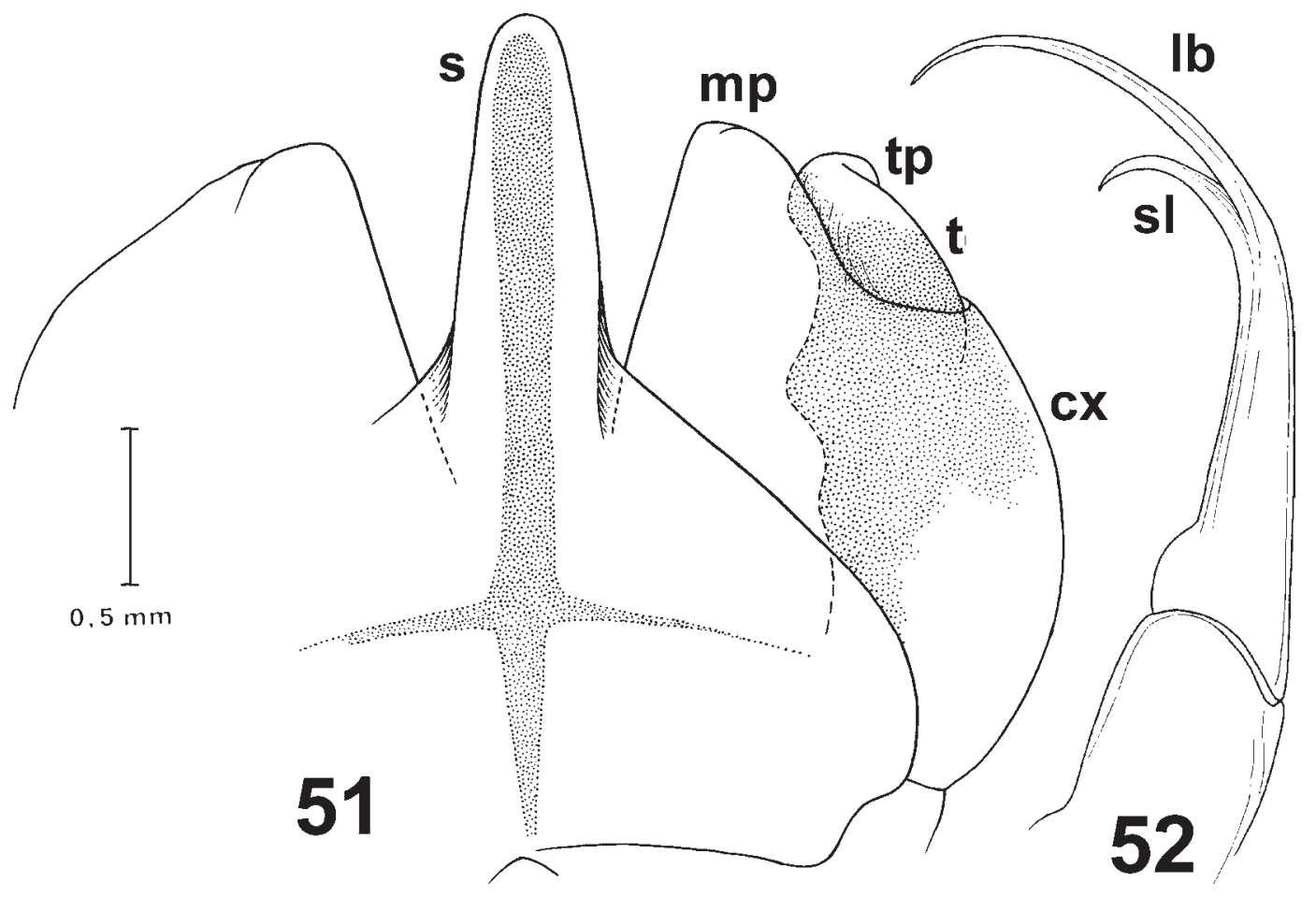

Figs 51-52. Dinematocricus aff. disjunctus Brölemann, 1913, O $\sigma^{7}$ from Maclay Coast. 50 - anterior gonopods, anterior view; 51 right posterior gonopod, posterior view. Designations explained in text.

Рис. 51-52. Dinematocricus aff. disjunctus Brölemann, 1913, о с Берега Маклая. 50 - передние гоноподы, спереди; 51 правый задний гонопод, сзади. Объяснения обозначений в тексте.

irregular spots/sigilla on internal surface of meso- and metazonae. Epiproct small, especially strongly flattened dorsoventrally. Paraprocts only faintly swollen along caudal margin (Fig. 36).

Legs ca. $2 / 3\left(O^{7}\right)$ or $1 / 3(+)$ as long as body height, fully devoid of sole pads, $\sigma^{7}$ coxae $3-5$ swollen ventrally (Fig. 37), a spine each above and below claw.

Gonopods (Figs 39-41). Anterior gonopods with a very strong, long, unusually broad, median, spear-shaped, apically rounded, sternal process (s), the latter being much longer/ higher than both coxa (cx) and telopodite (t) with its small, apical, rounded, caudolaterally directed process (tp); cx stout, with a strong, mesal, subtriangular projection (mp), $\mathbf{t}$ much more slender than cx. Posterior gonopods consisting of a shorter, relatively stout, subcylindrical coxa and a slender, much longer, bipartite telopodite; apicolateral branch (lb) the longest, $>2 \mathrm{x}$ as long as a similarly flagelliform solenomere (sl).

REMARKS. Based on Attems [1914, 1915], in particular the extended description and figs 19-21, at least the above $\sigma^{7}$ topotype is well identifiable as $D$. philistus, another species with a strongly spear-shaped central sternal process of the anterior gonopods (Figs 39, 40). However, this process s seems to be unusually hypertrophied in $D$. philistus compared to the remaining congeners from the same species group. Minor variations in D. philistus concern the colouration (uniformly blackish to blackish brown, vs. dark olive to redbrown in the description), body size ( $\sigma^{7}$ ca. $80 \mathrm{~mm}$ long and $6.0 \mathrm{~mm}$ wide, with $53 \mathrm{p}+\mathrm{T}$ segments, $v s . \geq 75 \mathrm{~mm}$ long and 8 $9.5 \mathrm{~mm}$ wide, with $49-59 \mathrm{p}+\mathrm{T}$ segments in the description), scobinae starting with segment 8 (and present until segment 38 , according to the description) etc. Syntypes of D. philis- tus (NHMW 2364): 1 dissected $\sigma^{7}, 1$ ๆ, 2 micro preparations, Indonesia, Molukken, Ambon, L.F. Beaufort leg.

\section{Dinematocricus aff. disjunctus Brölemann, 1913}

Figs 42-52.

Dinematocricus disjunctus Brölemann, 1913: 134, original description from the $\sigma^{\top}$ holotype from an unspecified locality in New Guinea.

MATERIAL. $5 \sigma^{\top} \sigma^{\top}, 4$ 우, 2 우 juv. (ZMUM), Papua New Guinea, Maclay Coast, near Kepoiak, $\mathrm{S}^{\circ} 45^{\prime}$, E146 $35^{\prime}$, forest litter, 13.II.1977, G.F. Kurcheva leg.

DESCRIPTION. Adults ca. 82-90 mm long, 7.0-9.0 mm wide, with 53-56p+T segments $\left(\sigma^{7},+\right)$, presumed subadults 52 or $54 \mathrm{~mm}$ long and $6.0 \mathrm{~mm}$ wide, with $52 \mathrm{p}+1 \mathrm{ap}+\mathrm{T}$ segments. Colouration in adults dark red-brown to dark grey-brown, pattern mostly clear due to metazonae and anterior parts of prozonae being cingulate and lighter reddish to yellowish (Figs 42, 44-46). Collum broadly flavous along both anterior and posterior margins (Fig. 42, 44). Epiproct similarly flavous (Fig. 46) or uniformly dark brown like head. Legs light to dark red-brown.

All characters as in Propodobolus sp., except as follows.

Tegument smooth and shining, mostly very delicately vermiculate. Interantennal isthmus ca. $2 \mathrm{x}$ diameter of antennal socket. Collum broadly and regularly rounded laterally, anterior and lateral margins clearly, but narrowly bordered. Midbody segments/rings faintly striate to striolate, more densely and clearly so ventrad, striations on dorsum above ozopore level completely obliterate. Scobinae present, starting with ring 8 and traceable at least until midbody segments: inconspicuous, paramedian, narrow, lunular pits sep- 
arated from each other by their own width and devoid of posterior fields. Ozopores small, inconspicuous disks, starting with ring 6 , each pore lying upon line/suture both just before metazona and longitudinal line. Numerous light and irregular spots/sigilla on internal surface of meso- and metazonae. Epiproct small, faintly concave near midway in lateral view, flattened dorsoventrally. Paraprocts only faintly swollen along caudal margin.

Legs ca. 1/2 $\left(\sigma^{7}\right)$ or $1 / 3(+)$ as long as body height; faint sole pads present only on $\sigma^{7}$ tarsi, $\sigma^{7}$ coxae $3-5$ swollen ventrally, a spine each above and below claw.

Gonopods (Figs 47-52). Anterior gonopods with a slender, central, apically rounded, sternal process (s), the latter being a little longer/higher than both coxa (cx) and telopodite (t) with its small, apical, rounded, caudolateral process (tp); cx stout, with a strong, mesal, rounded, subtriangular projection $(\mathbf{m p}), \mathbf{t}$ more slender than $\mathbf{c x}$. Posterior gonopods consisting of a shorter, relatively stout, subcylindrical coxa and a slender, much longer, bipartite telopodite; apicolateral branch (lb) the longest, $>3 \mathrm{x}$ as long as a similarly flagelliform solenomere (sl).

REMARKS. Based on Brölemann [1913], variations in $D$. aff. disjunctus compared to the original description concern the colouration (dark red-brown to dark grey-brown, with a mostly clearly cingulate pattern of lighter reddish or yellowish metazonae and anterior parts of prozonae, $v s$. dull ochraceous with brown caudal margins of metazonae in the description), body size (adults ca. $82-90 \mathrm{~mm}$ long and 7.0 $9.0 \mathrm{~mm}$ wide, with $53-56 \mathrm{p}+\mathrm{T}$ segments, $v s$. holotype $57 \mathrm{~mm}$ long and $5.0 \mathrm{~mm}$ wide, with $52 \mathrm{p}+2 \mathrm{ap}+\mathrm{T}$ segments in the original description), scobinae (starting with segment 8 and present at least until midbody rings, vs. ca. 14 and present until about segment 30 , according to the original description). In addition, since the anterior gonopods of the holotype show a slightly higher/longer, albeit similarly slender central sternal process and considerably higher/longer telopodites [Brölemann, 1913], the identity of the samples from Maclay Coast is bound to remain provisional.

\section{Dinematocricus aff. faucium Brölemann, 1913} Figs 53-76.

Dinematocricus faucium Brölemann, 1913: 129, original description from the $\sigma^{7}$ holotype from Thursday Island, Torres Strait Islands, Queensland, Australia.

MATERIAL. $11 \sigma^{7} \sigma^{7}, 13$ 우, 3 ㅇ juv. (ZMUM), Papua New Guinea, Trobriand Archipelago, Kiriwina Island, 24.I.1977, G.F. Kurcheva leg.

DESCRIPTION. Adults mostly ca. 85-120 mm long and 8.5-11.5 wide $\left(\sigma^{\top},+\right)$, with $53-59 \mathrm{p}+\mathrm{T}$ segments $\left(\sigma^{\top},+\right)$, presumed subadults 53-78 $\mathrm{mm}$ long and 5-6 mm wide, with $45 \mathrm{p}+4 \mathrm{ap}+\mathrm{T}, 53 \mathrm{p}+3 \mathrm{ap}+\mathrm{T}$ or $55 \mathrm{p}+3 \mathrm{ap}+\mathrm{T}$ segments. A single deviant $\sigma^{7}$ ca. $52 \mathrm{~mm}$ in length, ca. $5.5 \mathrm{~mm}$ in width, with $47 p+4 a p+T$ segments (see below). Colouration grey-brown to brown, pattern indistinctly cingulate due to darker brown metazonae and distinctly cingulate due to yellowish or light brown prozonae (Figs 53-60). Collum sometimes narrowly flavous along anterior margin (Fig. 53). Epiproct often similarly flavous dorsally (Figs 56, 60) Epiproct (Fig. 46) uniformly dark brown like head. Legs light to dark grey-brown. Presumed juveniles mostly greyish. Eye patches usually blackish brown, in adults each composed of 36-45 ommatidia arranged in 6-8 vertical rows.

All characters as in Propodobolus sp., except as follows.
Tegument smooth and shining, mostly very delicately vermiculate. Interantennal isthmus ca. $2 x$ diameter of antennal socket. Collum broadly and regularly rounded laterally, anterior and lateral margins, as well as caudolateral corner clearly, but narrowly bordered. Midbody segments/rings faintly striate to striolate, more densely and clearly so ventrad, striations on dorsum above ozopore level completely obliterate. Scobinae present, starting with ring 8 and traceable at least until last few segments: inconspicuous, paramedian, narrow, lunular pits separated from each other by ca. $3 \mathrm{x}$ their own width, each with a small posterior field (Figs 54, 59). Ozopores small, inconspicuous disks, starting with ring 6 , each pore lying upon line/suture both just before metazona and longitudinal line. Numerous light and irregular spots/ sigilla on internal surface of meso- and metazonae. Epiproct small, faintly concave near proximal third in lateral view, flattened dorsoventrally. Paraprocts very clearly swollen along caudal margin (Figs 56, 60).

Legs ca. 1/2 $\left(\sigma^{7}\right)$ or $1 / 3(+)$ as long as body height; distinct sole pads present only on $\sigma^{\top}$ tarsi, gradually reduced towards posterior body third. $\sigma^{7}$ coxae 3-5 swollen ventrally (Fig. 58), a spine each above and below claw.

Gonopods (Figs 61-66). Anterior gonopods with a strong, central, distally broadened and apically narrowly rounded, sternal process (s), the latter being much longer/higher than both coxa (cx) and telopodite (t) with its small, apical, rounded, caudolateral process (tp); cx stout, with a moderate, elongate, mesal, subtriangular projection (mp), t more slender than cx. Posterior gonopods consisting of a shorter, relatively stout, subcylindrical coxa and a slender, much longer, bipartite telopodite; apicolateral branch (lb) the longest, $>3 \mathrm{x}$ as long as a similarly flagelliform solenomere (sl).

REMARKS. Among the $\sigma^{7} \sigma^{7}$ in the above series the smallest one (length ca. $52 \mathrm{~mm}$, width ca. $5.5 \mathrm{~mm}$, with $47 p+4 a p+T$ segments) superficially looks much the same as the others (Figs 69-74), but the $\sigma^{7}$ sole pads are missing, the scobinae are only ca. $2 \mathrm{x}$ apart from each other and show better developed posterior fields (Fig. 70), whereas the gonopods (Figs 67, 68, 71-74), both anterior and posterior, differ in the central sternal process (s) of the anterior gonopods being slightly bifid, club-shaped and considerably shorter than the telopodite (t), the medial projections (mp) of the coxite (cx) are relatively more prominent, and the entire posterior gonopod is much shorter. This sole $\sigma^{7}$ may prove to belong to a different species, but given the entire body of evidence, including the smallest body size, the increased number of apodous segments, the absence of sole pads, the clearly shortened posterior gonopods etc., on balance we tend to regard that deviant $\sigma^{7}$ as abnormal and somewhat underdeveloped, perhaps premature, and thus it seems conspecific with the other material. The development of most Spirobolida being hemianamorphotic, that of the gonopods in some members has long been known to be gradual [Mauriès, 1980; Enghoff et al., 1993; Bond et al., 2003], in D. aff. faucium likely getting modified at least between certain prematuration moults (cf. above under D. aff. bionus).

Among the other variable characters, we can mention a lighter, rather vague dorsal spot on the dorsal side of the epiproct that is noticeable in several specimens. Carl [1918] distinguished that morph as the variety fulvosignatus, from an unspecified place in New Guinea, in which that light spot was clear. This variety still remains such and has no status in the nomenclature.

Some of the features of D. faucium which Attems [1914] recorded from samples from the mainland of eastern Papua 

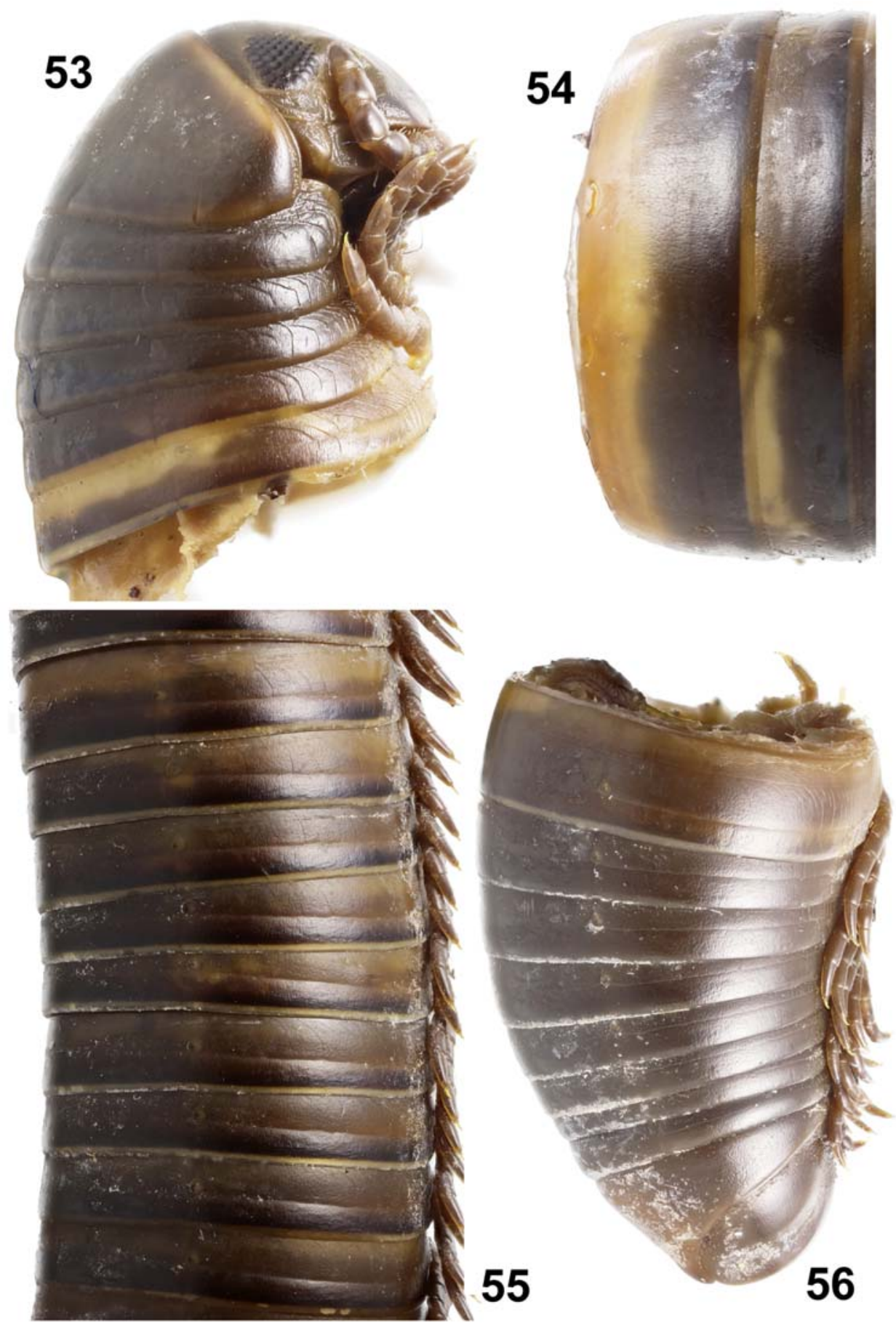

Figs 53-56. Dinematocricus aff. faucium Brölemann, 1913, larger $0^{7}$ from Kiriwina Island. 53 - anterior part of body, lateral view; 54 - body segments 8 and 9, dorsal view; 55 - middle part of body, lateral view; 56 - posterior part of body, lateral view. Pictures by K.V. Makarov, taken not to scale.

Рис. 53-56. Dinematocricus aff. faucium Brölemann, 1913, крупный О7 с острова Киривина. 53 - передняя часть тела, сбоку; 54 сегменты тела 8 и 9, сверху; 55 - средняя часть туловища, сбоку; 56 - задняя часть тела, сбоку. Фотографии К.В. Макарова, сняты без масштаба.

New Guinea differed from the original description so significantly that Jeekel [2001] suggested that they belonged to a species other than $D$. faucium. We believe that until more comparative material becomes available for study, the identity of the Kiriwina material is bound to remain but provi- sional. According to Brölemann [1913], the holotype from an island off Queensland, Australia was $112 \mathrm{~mm}$ long, 9.5 $\mathrm{mm}$ wide, with $54 \mathrm{p}+1 \mathrm{ap}+\mathrm{T}$ segments, blackish brown with red-brown cingula along the caudal margins of metazonae and a bright brown-red telson; scobinae are present on seg- 

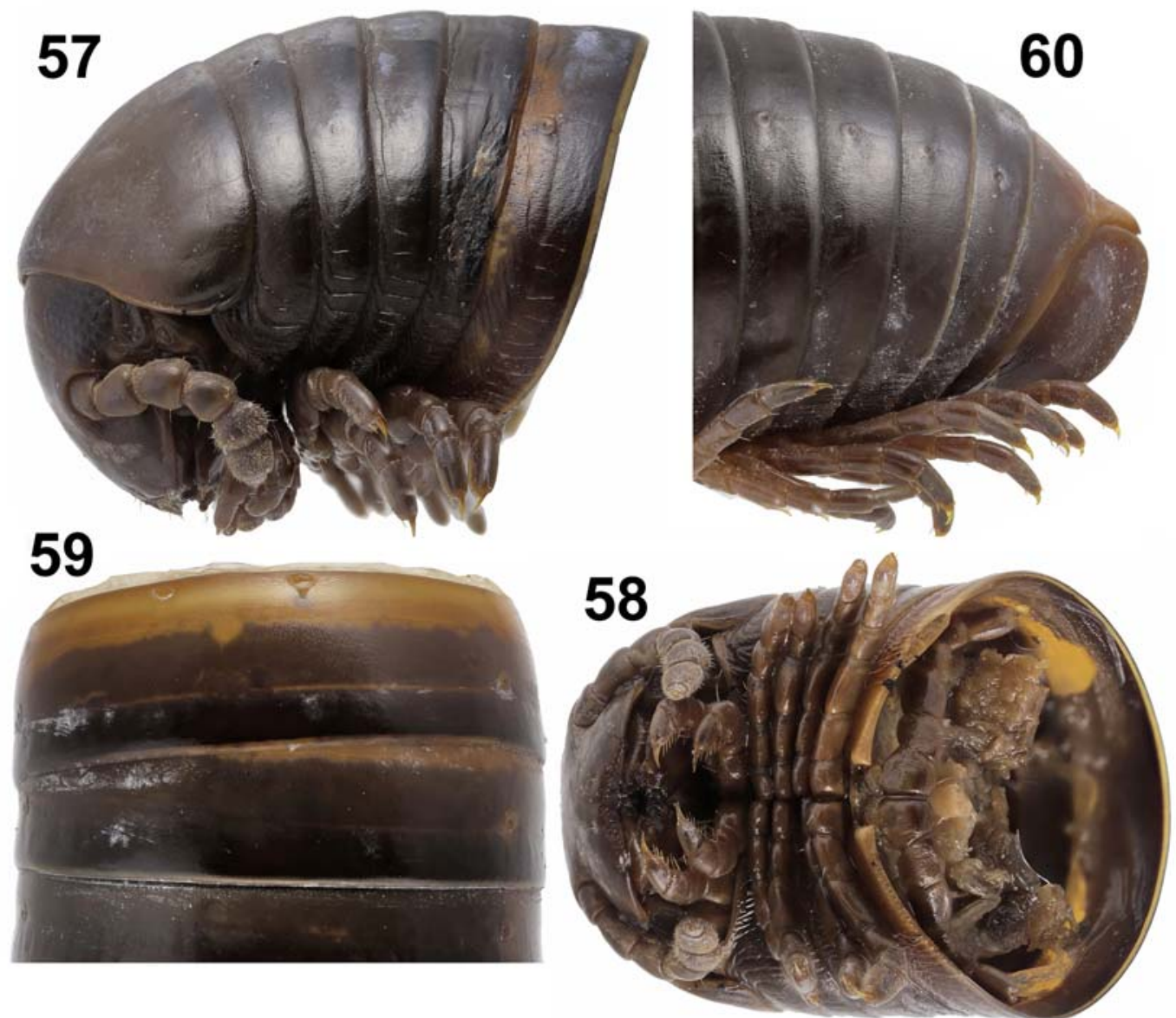

Figs 57-60. Dinematocricus aff. faucium Brölemann, 1913, larger $0^{7}$ from Kiriwina Island. 57, 58 - anterior part of body, lateral and ventral views, respectively; 59 - midbody segments, dorsal view; 60 - posterior part of body, lateral view. Pictures by K.V. Makarov, taken not to scale.

Рис. 57-60. Dinematocricus aff. faucium Brölemann, 1913, крупный О с острова Киривина. 57, 58 - передняя часть тела, соответственно сбоку и снизу; 59 - среднетуловищные сегменты тела, сверху; 60 - задняя часть тела, сбоку. Фотографии К.В. Макарова, сняты без масштаба.

ment 8 to about $36^{\text {th }}$, separated from each other by about $1.5 \mathrm{x}$ their diameter and each showing a posterior field; the anal valves are bordered near the caudal margin; and $\sigma^{7}$ tarsi are devoid of sole pads. The anterior gonopods, however, are exactly the same as in Figs 61, 62, 65 and 66.

\section{Genus Eurhinocricus Brölemann, 1903}

Type species: E. biolleyi Brölemann, 1903, by monotypy.

COMMENT. This rather large genus of Rhinocricidae presently comprises 34 species or subspecies which are mostly endemic to South and Central America, ranging from Brazil and Bolivia in the south to northern Mexico in the north (also introduced to the southern U.S.A.) [Jeekel, 2001; Marek et al., 2003; https://bugguide.net/node/view/103681]. Only two species are remarkable exceptions, one from the Caroline Islands and the other from the Marianas, both in Micronesia [Jeekel, 2001]. Following both Attems [1914] and Hoffman [1955], this tetraconocerate genus is distinguished through the structure of the posterior gonopod, in which the solenomere is a shorter mesal branch, while the main, outer branch is flattened, blade-shaped and apically usually subtruncate, not truly flagelliform. As noted above, some $E u$ rhinocricus species from the Antilles also fit in the diagnoses of Australocricus and Propodobolus (cf. Bond, Sierwald [2002]).

\section{Eurhinocricus sp.}

Figs 75-85.

MATERIAL. $3 O^{\top} O^{\top}, 1+1$ juv. (ZMUM), Fiji, Viti Levu Island, Suva Botanical Garden, 16.III.1977, G.F. Kurcheva leg.

DESCRIPTION. Length 18-23 $\left(\sigma^{7}\right)$ or $25 \mathrm{~mm}(+)$, width $1.8-2.1\left(\mathrm{O}^{7}\right)$ or $2.4 \mathrm{~mm}(+)$. Adults with $36-38 \mathrm{p}+1-2 \mathrm{ap}+\mathrm{T}$ segments. Colouration rather uniformly grey- to red-brown (Figs 75-80), only antennae and legs light red-yellow, and eye patches blackish; a faint dorsal pattern of lighter, vague, paramedian, rather wide stripes consisting of comma-shaped spots on each ring (Fig. 79).

Body cylindrical, postcollum constriction very faint (Fig. 77). Head as usual, three small central teeth at fore margin of and a superficial, fine, axial suture on labrum, with ca. $10+10$ labral and $2+2$ supralabral setae. Eye fields subcircu- 


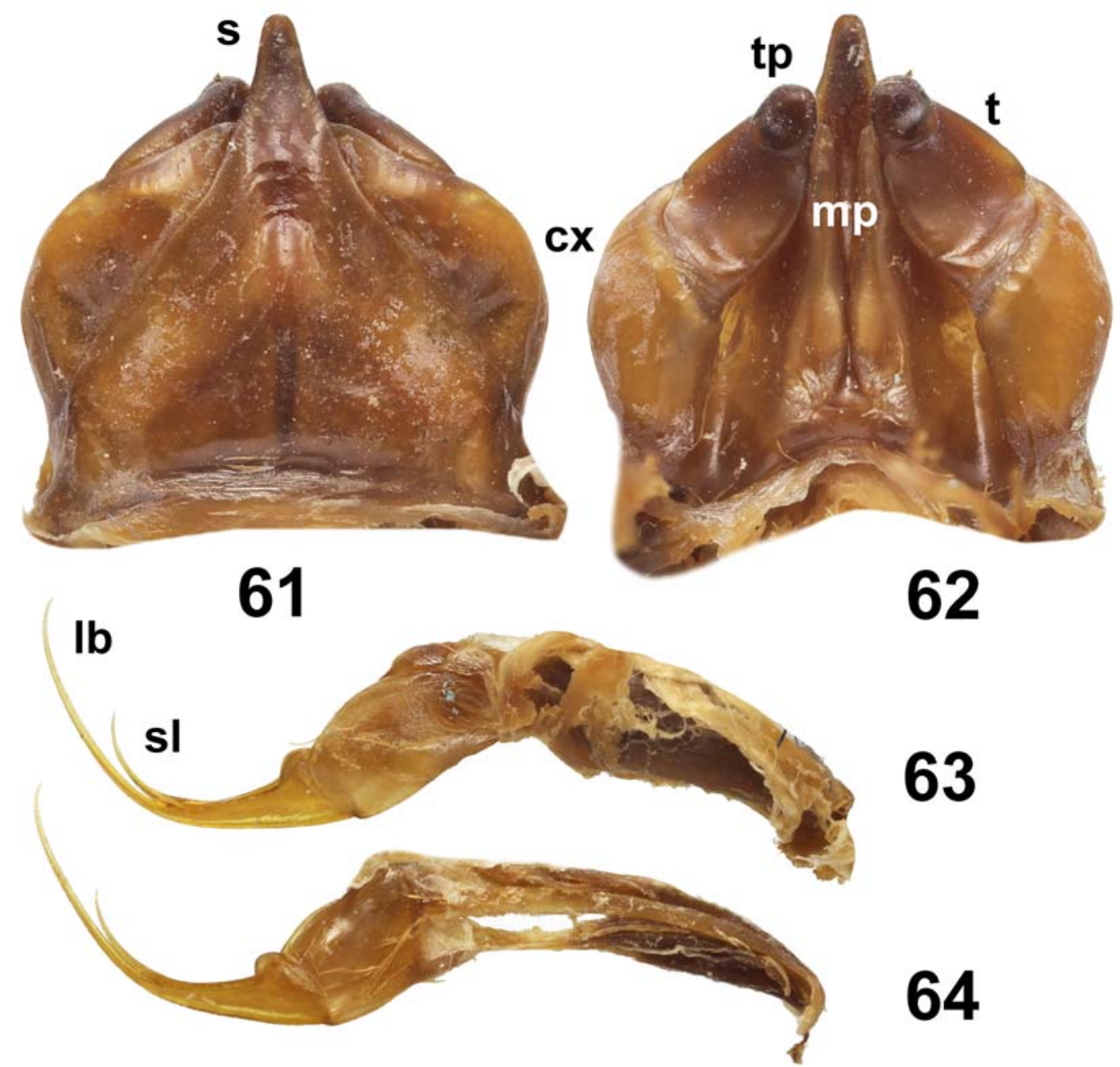

Figs 61-64. Dinematocricus aff. faucium Brölemann, 1913, larger $0^{7}$ from Kiriwina Island. 61, 62 — anterior gonopods, anterior and posterior views, respectively; 63, 64 - posterior gonopods, anterior and posterior views, respectively. Designations explained in text. Pictures by K.V. Makarov, taken not to scale.

Рис. 61-64. Dinematocricus aff. faucium Brölemann, 1913, крупный O’ с острова Киривина. 61, 62 - передние гоноподы, соответственно спереди и сзадиг; 63, 64 - задние гоноподы, соответственно спереди и сзади. Объяснения обозначений в тексте. Фотографии К.В. Макарова, сняты без масштаба.

lar, large, ommatidia flat, ca. 32-34 per patch, arranged in 6-7 vertical rows (Figs 75, 76), isthmus ca. 2x diameter of eye patch (Fig. 77). Antennae short and clavate, curved anteroventrad, in situ stretchable laterally behind caudal margin of collum; antennomeres 1-6 subequal in length, antennomeres 5-7 considerably more strongly setose than others, $7^{\text {th }}$ shortest, $8^{\text {th }}$ with four small apical cones (Figs 7577). Tegument bare, smooth and mostly shining (Figs 75 80). Collum very broadly rounded and clearly, but rather narrowly bordered laterally (Figs 75, 76). Midbody segments/rings devoid of evident sutures between zonae; mesoand metazonae unusually distinctly and densely striate across entire circumference, slightly more densely so ventrad, ca. 6-8 striae per square equal to their length just below ozopore level, longitudinal on metazonae, slightly oblique and directed dorsad on mesozonae, very delicate, dense, vertical and often confused on prozonae; striations on meso- and metazonae mostly regular, only in places abbreviated, confused only mid-dorsally and near ozopore (Figs 75-80).
Scobinae absent. Ozopores small, inconspicuous, starting with segment/ring 6, each pore lying upon line/suture just before metazona on a vague and minute boss. Telson (Figs $75,80)$ as usual, epiproct flat, caudally rounded and very small; paraprocts strongly and regularly convex, smooth, not bordered along caudal margin, with only a small and inconspicuous gutter between both valves; hypoproct strongly transverse and caudally rounded. Only $\sigma^{7}$ segment 7 clearly swollen ventrally (Fig. 75), a complete ring due to a strong ventral bridge in caudal half. Very small and numerous, light and irregular spots/sigilla on internal surface of mesoand metazonae (Fig. 77).

Legs relatively long and slender $\left(\sigma^{\top},+\right)$, ca. $2 / 3-3 / 4$ as long as midbody height, each usually with a spine below and above claw; only $0^{7}$ legs 1 and 2 somewhat shorter; ventral sole pads wanting (Fig. 75-78, 80).

Gonopods (Figs 81-85). Anterior gonopods with a strong, median, slender, finger-shaped, apically rounded, sternal process (s), the latter only slightly longer than both coxa 


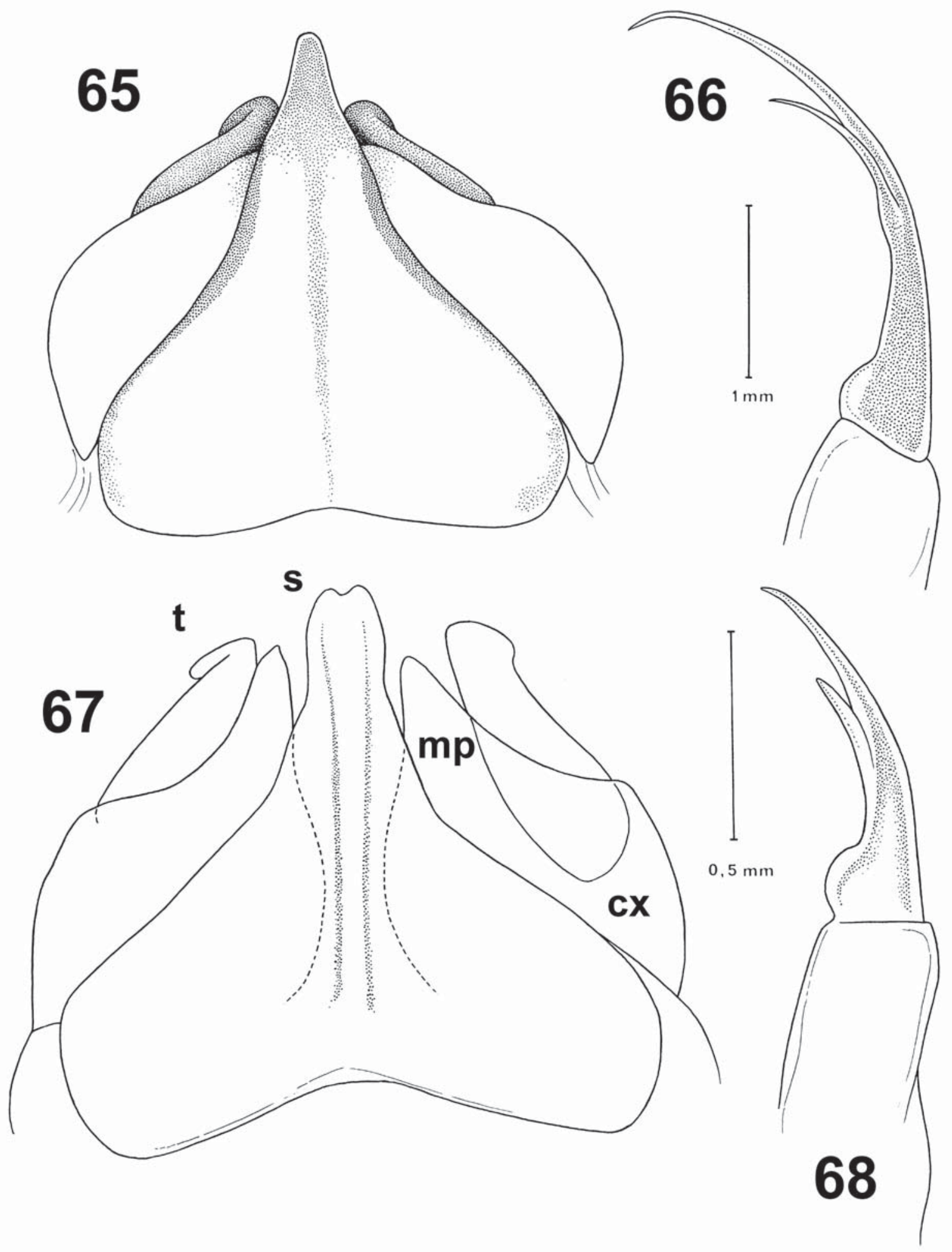

Figs 65-68. Dinematocricus aff. faucium Brölemann, 1913, larger $(65,66)$ and smaller $(67,68) 0^{7} 0^{7}$ from Kiriwina Island. 65,67 anterior gonopods, anterior view; 66, 68 - right posterior gonopod, anterior view.

Pис. 65-68. Dinematocricus aff. faucium Brölemann, 1913, крупный $(65,66)$ и мелкий $(67,68)$ o $^{7}$ c $^{7}$ острова Киривина. $65,67-$ передние гоноподы, спереди; 66, 68 - правый задний гонопод, спереди. 

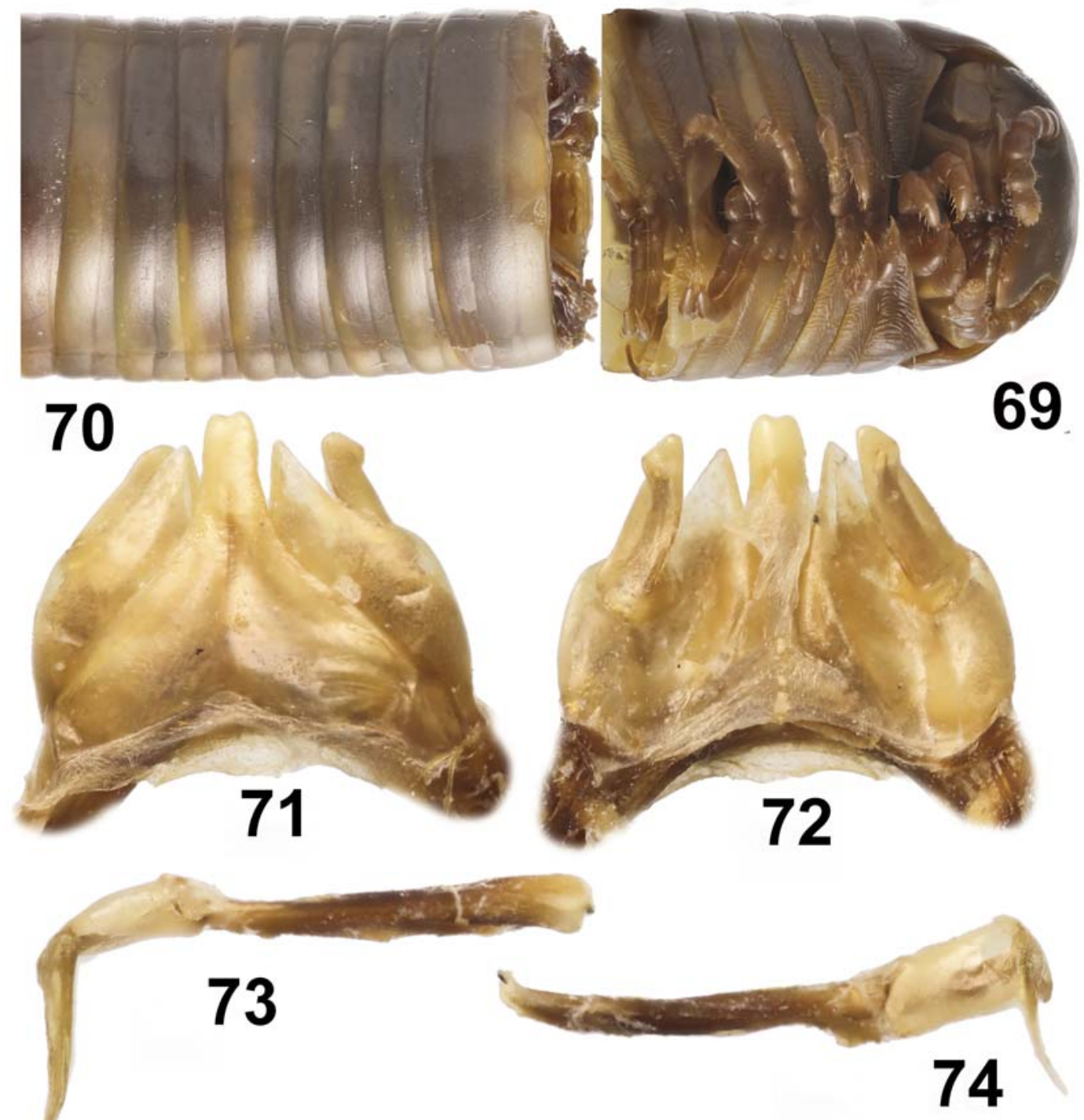

Figs 69-74. Dinematocricus aff. faucium Brölemann, 1913, smaller $\sigma^{7}$ from Kiriwina Island. 69 - anterior part of body, ventral view; 70 - midbody segments, dorsal view; 71, 72 - anterior gonopods, anterior and posterior views, respectively; 73, 74 - posterior gonopods, anterior and posterior views, respectively. Pictures by K.V. Makarov, taken not to scale.

Рис. 69-74. Dinematocricus aff. faucium Brölemann, 1913, мелкий о7 с острова Киривина. 69 - передняя часть тела, снизу; $70-$ среднетуловищные сегменты, сверху; 71, 72 - передние гоноподы, соответственно спереди и сзади; 73, 74 - задние гоноподы, соответственно спереди и сзади. Фотографии К.В. Макарова, сняты без масштаба.

(cx) and telopodite (t) with its small, apical, rounded, laterally directed process (tp); cx the largest, with a strong, mesal, subtriangular, ventrally indistinctly tuberculate projection (mp) and a moderate apicolateral swelling (sw), both subtending a relatively slender t. Posterior gonopods connected with a small, membranous, ribbon-shaped sternum, each gonopod consisting of a short, stout, subcylindrical coxa (cx2) and a slender, much longer, bipartite telopodite (t2); apicolateral branch (lb) the largest, slender throughout, ribbon-shaped, slightly curved in subapical part, subtruncate apically; mesal branch (= solenomere, sl) much shorter, bacilliform, originating at about basal $1 / 3$ and extending until about $1 / 5$ of $\mathbf{t} 2$.
REMARKS. Superficially, had it not been for Fiji as the place of provenance, this species could have easily been described as new, because no Eurhinocricus sp. has ever been recorded south of the Mariana Islands in the southern Pacific. The species from Fiji is highly peculiar and easy to distinguish primarily in showing the metazonae clearly striated across the circumference (Figs 75, 76, 78-80), while the gonopods, both anterior and posterior, are with several characteristically shaped outgrowths (Figs 81-85). Moreover, the above specimens differ well from a (morphologically similar) unidentified species and the two hitherto described congeners from Micronesia at least in gonopodal structure. Thus, E. naufragus Carl, 1918, from Atoll Uliti, Carolines, 


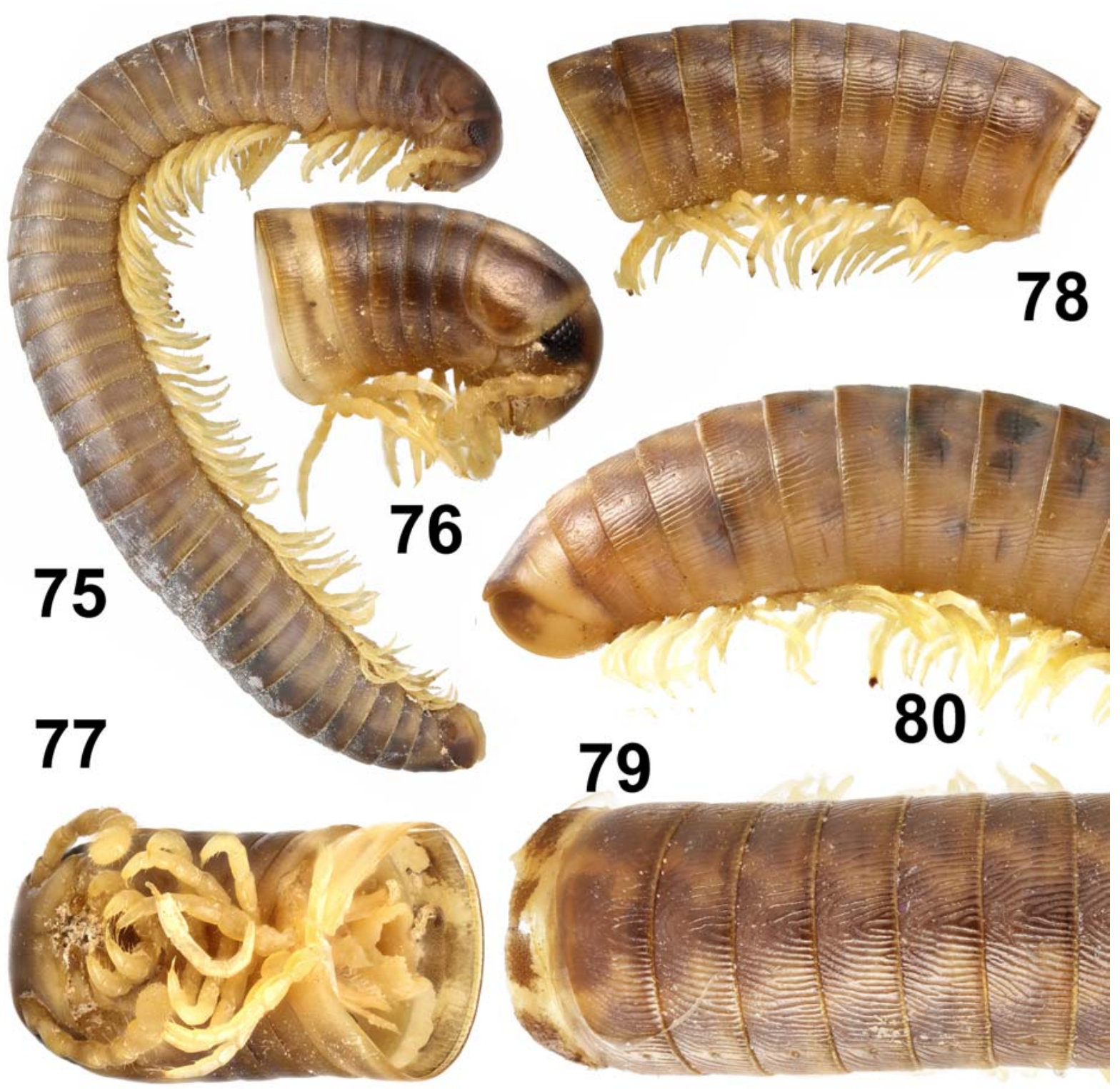

Figs 75-80. Eurhinocricus sp., $0^{7}$ from Suva. 75 - habitus, lateral view; 76, 77 - anterior part of body, lateral and ventral views, respectively; 78, 79 - midbody segments, lateral and dorsal views, respectively; 80 - posterior part of body, lateral view. Pictures by K.V. Makarov, taken not to scale.

Рис. 75-80. Eurhinocricus sp., О7 из города Сува. 75 - общий вид, сбоку; 76, 77 - передняя часть тела, соответственно сбоку и снизу; 78, 79 - средняя часть тела, соответственно сбоку и сверху; 80 - задняя часть тела, сбоку. Фотографии К.В. Макарова, сняты без масштаба.

is a little larger (28-33 mm long and $3.5 \mathrm{~mm}$ wide, vs. $18-25$ $\mathrm{mm}$ and $1.9-2.4 \mathrm{~mm}$ wide), shows considerably finer striations on meso- and metazonae ( $v s$. far more strongly developed ones, Figs 75-80), the central sternal process of its anterior gonopods is parallel-sided ( $v s$. broader at base, Figs 81-84), the telopodites are smaller (vs. larger), while the solenomere of the posterior gonopod is distinctly longer, nearly reaching the tip of the main branch ( $v s$. considerably shorter, Figs 81, 82, 85) [Carl, 1918]; E. saipanus Verhoeff, 1937, from Saipan (= Guam), Marianas, so far as it can be derived from a very brief (and only verbal) original description [Verhoeff, 1937], as well as based on type microscopic slides, shows a stronger, central, sternal process and unusu- ally short telopodites of the anterior gonopods (vs. weaker and longer, respectively, Figs 81-84), while the main branch of the posterior gonopod is much more slender, suberect and truncate apically ( $v s$. broader, curved subapically and subtruncate, Figs 81, 82, 85). The type material of E. saipanus, in the Zoological Museum in Munich (= Bayerische Zoologische Staatssammlung in München), contains one $\sigma^{\gamma}$ and one + , both partly in alcohol (ZSMA20070540) and partly in microscopic slides A20031550, A20031551 and A20031552 (Figs 86-88), of which A20031551 and A20031552 are designated herewith as representing the lectotype to ensure that the species is based on $\sigma^{7}$ material. The gonopods of the lectotype (Figs 89,90 ) agree not only with 

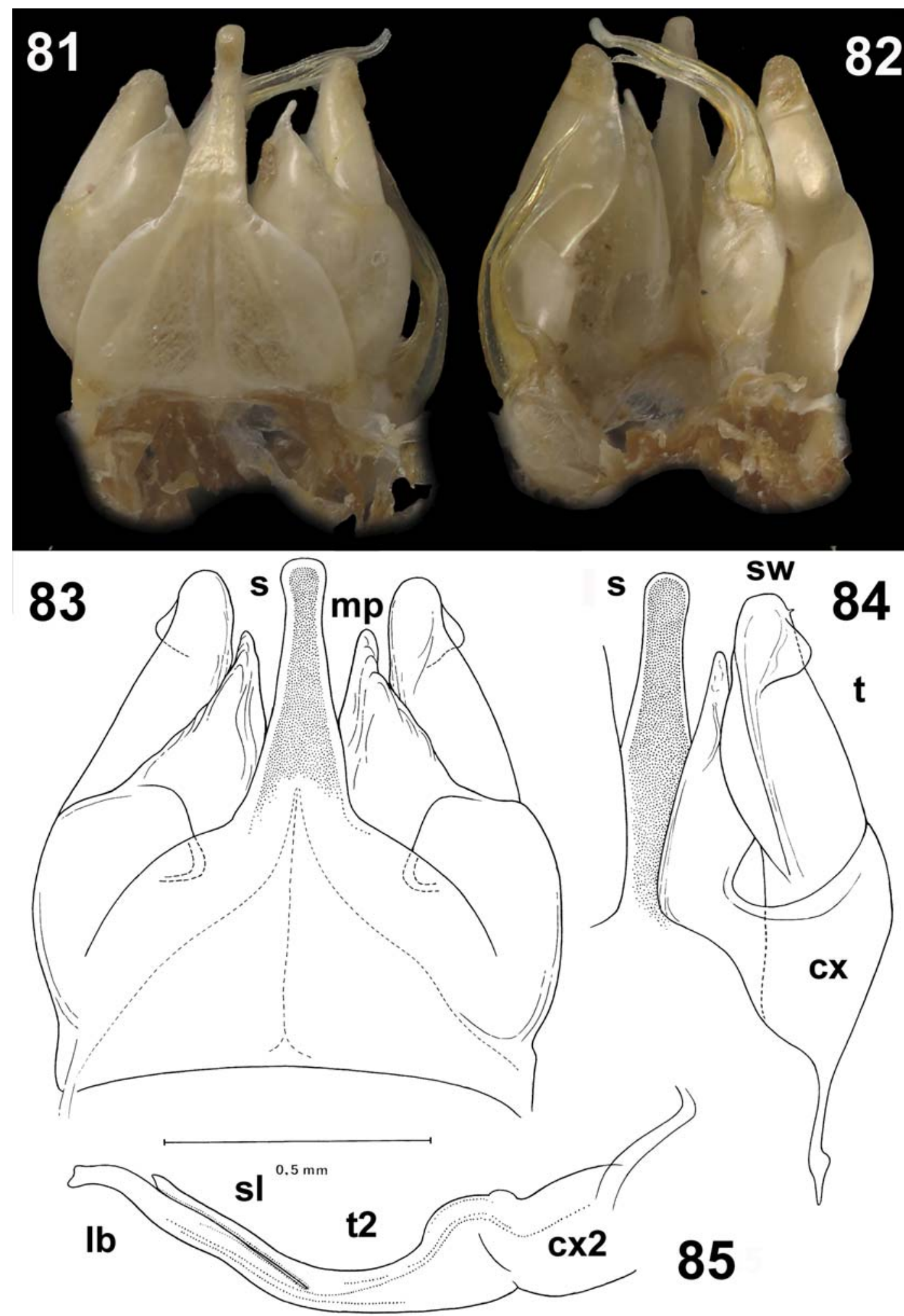

Figs 81-85. Eurhinocricus sp., $\mathrm{O}^{7}$ from Suva. 81, 82 - both anterior gonopods and left posterior gonopod in situ, anterior and posterior views, respectively; 83,84 - anterior gonopods, anterior and posterior views, respectively; 85 - right posterior gonopod, posterior view. Designations explained in text. Pictures by K.V. Makarov, taken not to scale.

Рис. 81-85. Eurhinocricus sp., о7 из города Сува. 81, 82 - оба передних гонопода, соответственно спереди и сзади; 83, $84-$ передние гоноподы, соответственно спереди и сзади; 85 - правый задний гонопод, сзади. Объяснения обозначений в тексте. Фотографии К.В. Макарова, сняты без масштаба. 


\section{6}
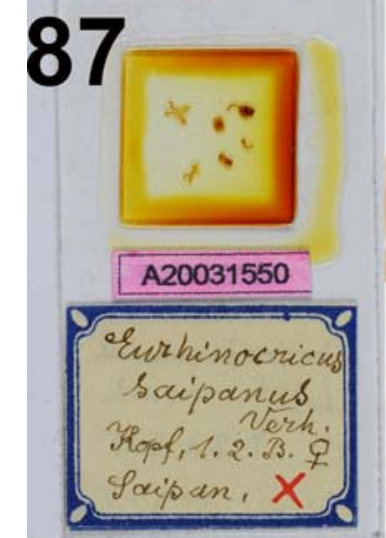

\section{8}

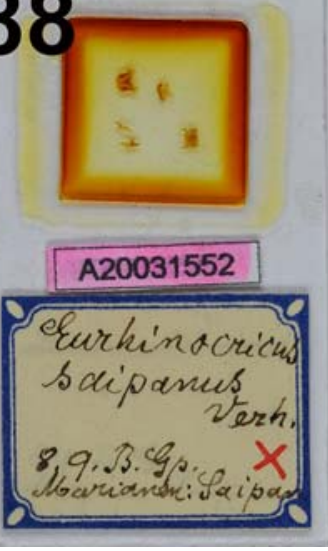

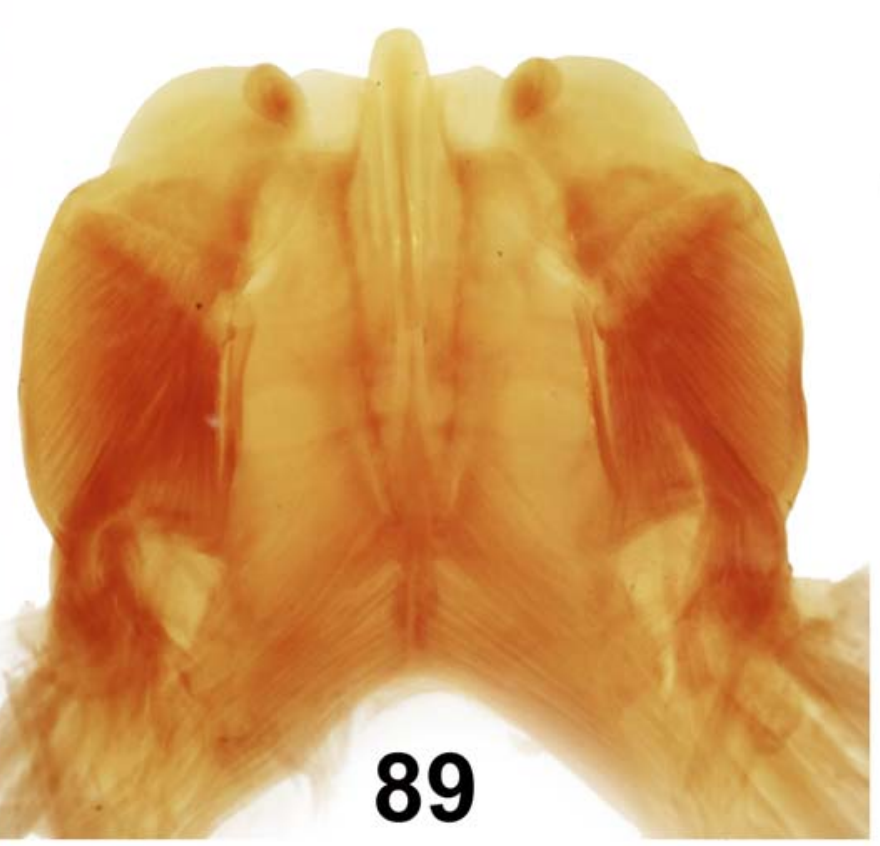

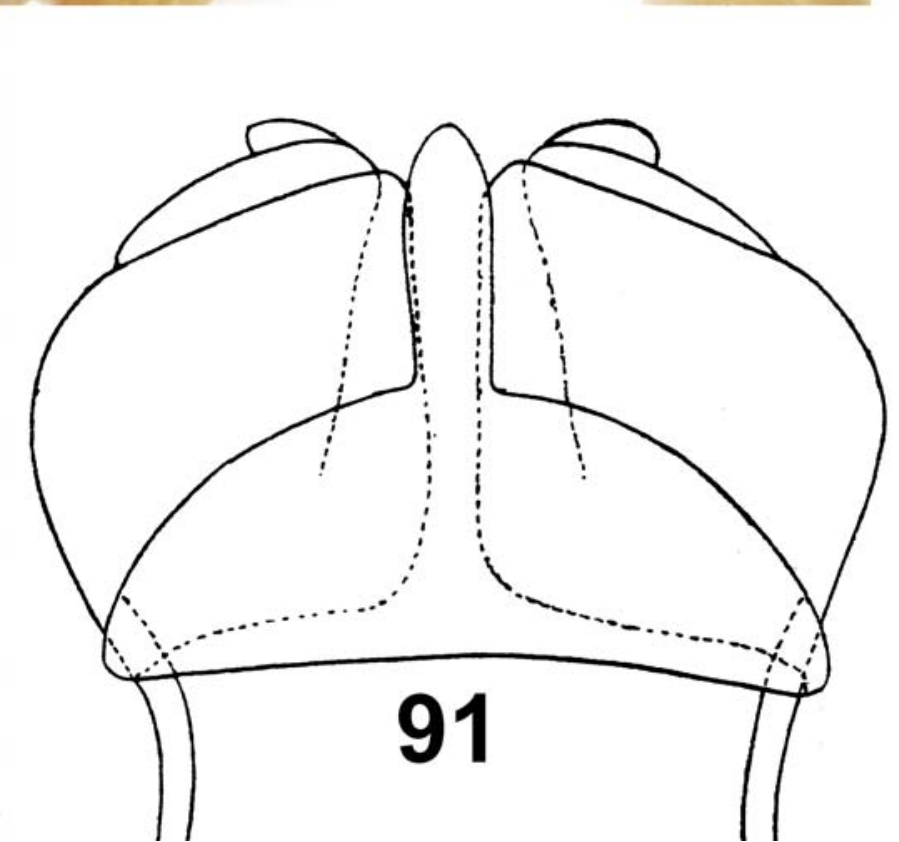

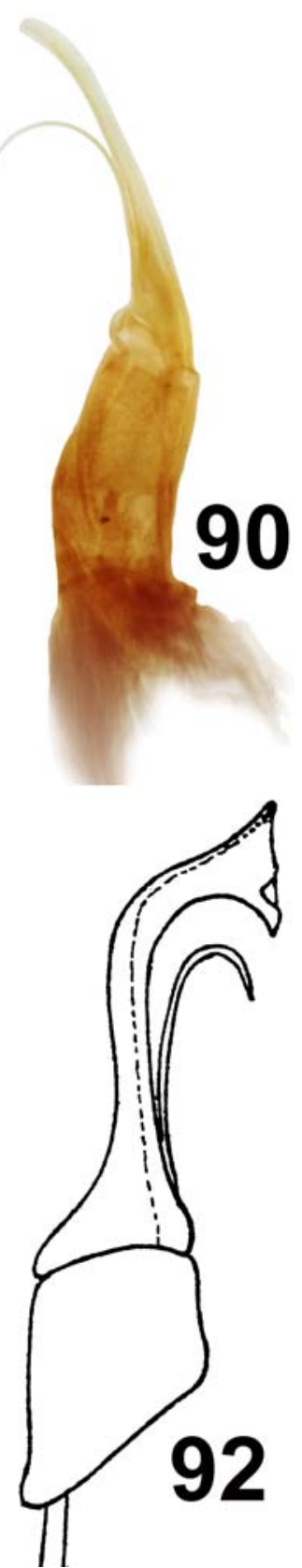

Figs 86-92. Eurhinocricus saipanus Verhoeff, 1937, type microscopic slides, including the gonopods of the lectotype, from Saipan, (= Guam), Marianas, and Eurhinocricus sp., o from Yap Islands, Carolines, after Takakuwa [1942].

Рис. 86-92. Eurhinocricus saipanus Verhoeff, 1937, типовые микропрепараты, включая гоноподы лектотипа, с острова Сайпан (= Гуам), Марианские острова, и Eurhinocricus sp., ơ с островов Яп, Каролинские острова, по: Takakuwa [1942].

Verhoeff's [1937] brief account, which is natural, but also considerably with what Takakuwa [1942], in his review of the myriapod fauna of Micronesia, referred to as Eurhinocricus sp., from Yap Islands, Carolines. Takakuwa [1942] totally omitted E. saipanus, apparently being unaware of it, but he described and illustrated his closer unidentified Eurhinocricus sp. as being $35 \mathrm{~mm}$ long and $3.5 \mathrm{~mm}$ wide, and generally rather well agreeing in gonopodal characters to E. saipanus (Figs 89, 90). Especially the anterior gonopods are similar, including the unusually short telopodites. Still the Yap (Figs 91, 92) and Saipan (Figs 89, 90) sam- ples fail to look conspecific because the main branch of the posterior gonopod in the former species is much more strongly expanded and elaborate distally compared to the latter one. In any event, more comparative material is clearly necessary to assess the Eurhinocricus diversity in Microand Melanesia. At the moment, all we can state is that Micronesia supports 2-3 species of Eurhinocricus. Strangely enough, Marek et al. [2003], in their global catalogue of Rhinocricidae, also omitted E. saipanus, even though Jeekel's [2001] regional catalogue had provided a full account of that species. 

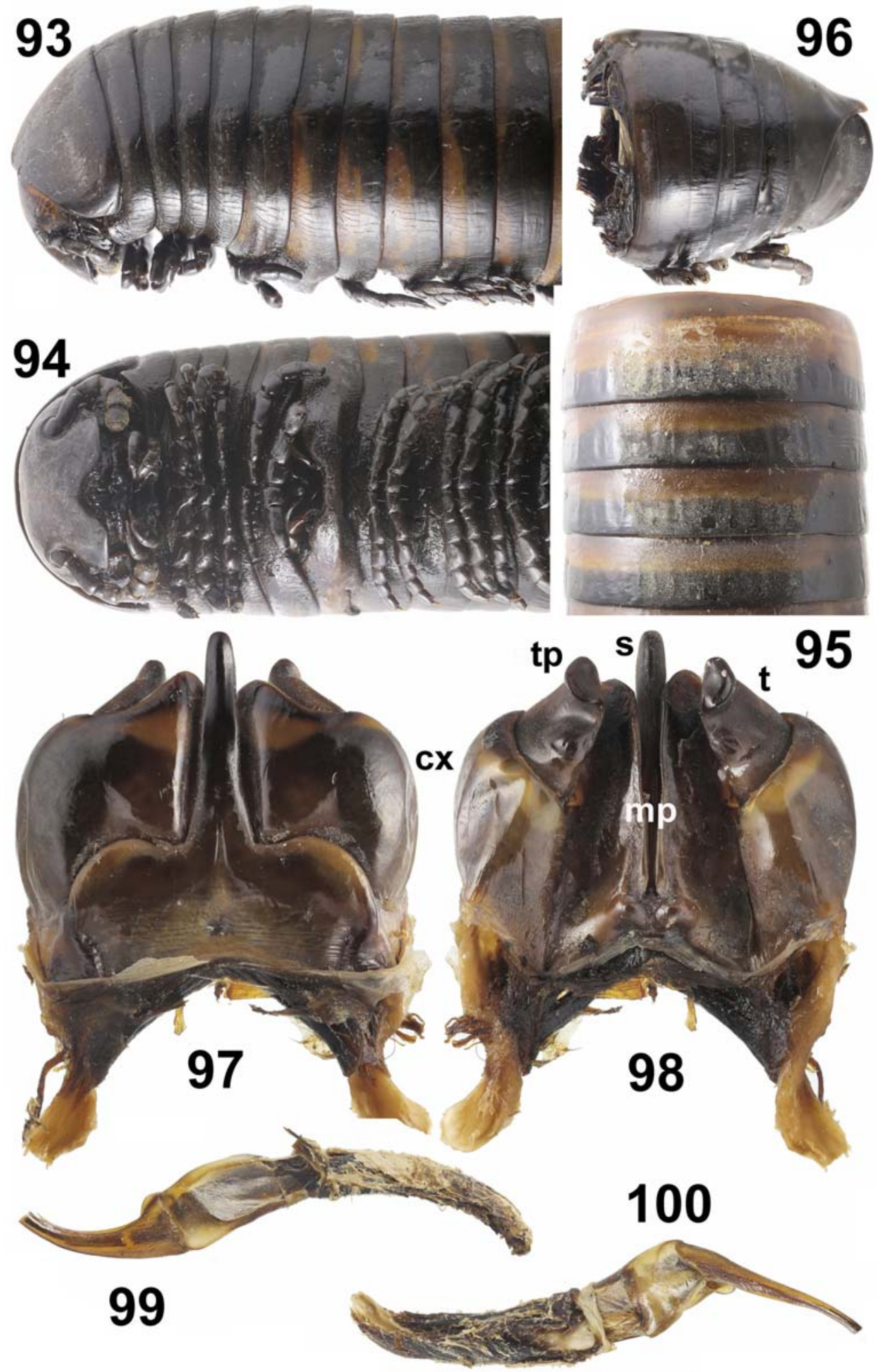

Figs 93-100. Salpidobolus alokistus (Attems, 1914), $0^{7}$ near-topotype from Lae. 93, 94 - anterior part of body, lateral and ventral views, respectively; 95 - midbody segments, dorsal view; 96 - posterior part of body, lateral view; 97, 98 - anterior gonopods, anterior and posterior views, respectively; 99, 100 - left posterior gonopod (tip of $\mathbf{l b}$ branch broken off), posterior and posterolateral views, respectively. Pictures by K.V. Makarov, taken not to scale.

Рис. 93-100. Salpidobolus alokistus (Attems, 1914), О7 почти топотип из порта Lae. 93, 94 - передняя часть тела, соответственно сбоку и снизу; 95 - среднетуловищные сегменты, сверху; 96 - задняя часть тела, сбоку; 97, 98 - передние гоноподы, соответственно спереди и сзади; 99, 100 - левый задний гонопод (кончик ветви $\mathbf{l b}$ обломан), соответственно сзади и одновременно сзади и сбоку. Фотографии К.В. Макарова, сняты без масштаба. 
Because the Fiji Islands support a wealth of rhinocricid species, mostly quite enigmatic and some even based on $q$ material alone, whereas the ZMUM samples come from a botanical garden, hence perhaps introduced, falling in synonymy seems to us very likely. As a result, we properly document and illustrate the ZMUM material even as not fully identified, in the hope that someday the taxonomic mess concerning the fauna of Fiji steps back, and the species becomes properly determined. Our Fiji samples are easily distinguished primarily in the body striations being unusually distinct and dense, covering the entire circumference of the meso- and metazonae (Figs 75, 76, 78-80), while the gonopods are also highly characteristic (Figs 81-85).

Jeekel [2001] provided a catalogue that contained as many as 24 species of Rhinocricidae known to occur in Fiji alone, most of which he assigned to Dinematocricus. Such an allocation was specially emphasized, and it was based on Jeekel's vast personal experience in the study of Fiji's rhinocricids, who found them all being tetraconocerate. In contrast, Evenhuis [2008], (http://hbs.bishopmuseum.org/Fiji/ checklists/diplopoda.html), listed most in Salpidobolus, a polyconocerate genus. We prefer to follow Jeekel's [2001] opinion as obviously more credible. Because at least five species described from Fiji are listed among Rhinocricidae, Spirobolida or even Juliformia of uncertain status [Jeekel, 2001], the only thing we believe appropriate at this stage is just to publish the first formal record of the genus Eurhinocricus from Fiji.

\section{Genus Salpidobolus Silvestri, 1897}

Type species: Rhinocricus meyeri Silvestri, 1897, by original designation.

COMMENT. This large genus of Rhinocricidae presently comprises 30 Australasian species or subspecies ranging from Borneo and Sulawesi in the west, Micronesia and Melanesia in the north, to eastern Papua New Guinea in the east [Jeekel, 2001]. Following Attems [1914] and, especially, Jeekel [2001], this genus is polyconocerate, being distinguished only through the numerous (more than the minimum number of four) apical sensory cones on each antenna. This sole distinction between Dinematocricus and Salpidobolus is so weak that Hoffman [1974] formally synonymized the former genus under the latter one. In addition, some species were first described in Dinematocricus and only later transferred to Salpidobolus.

Still we strictly follow Jeekel's [2001] classification for consistency reasons alone.

\section{Salpidobolus alokistus (Attems, 1914) Figs 93-101.}

Polyconoceras alokistus Attems, 1914: 312, original description from a $\sigma^{7}$ and a $q$ syntype from near Cape Arkona, Huon Gulf, Papua New Guinea.

Salpidobolus alokistus — Jeekel, 2001: 33.

MATERIAL. $1 \sigma^{7}$ (ZMUM), Papua New Guinea, S6 $44^{\prime} 0^{\prime \prime}$, $\mathrm{E} 147^{\circ} 0^{\prime} 0^{\prime \prime}$, Port Lae, botanical garden, wet forest, 18.II.1977, G.F. Kurcheva leg.

BRIEF REDESCRIPTION. Length ca. $160 \mathrm{~mm}$, width $14.5 \mathrm{~mm}$, with 55+T segments. Colouration blackish greybrown with olive tinge, pattern clearly cingulated due to particularly dark metazonae and lighter, mostly brown proand mesozonae; tip of epiproct and legs dark brown (Figs 93-96).

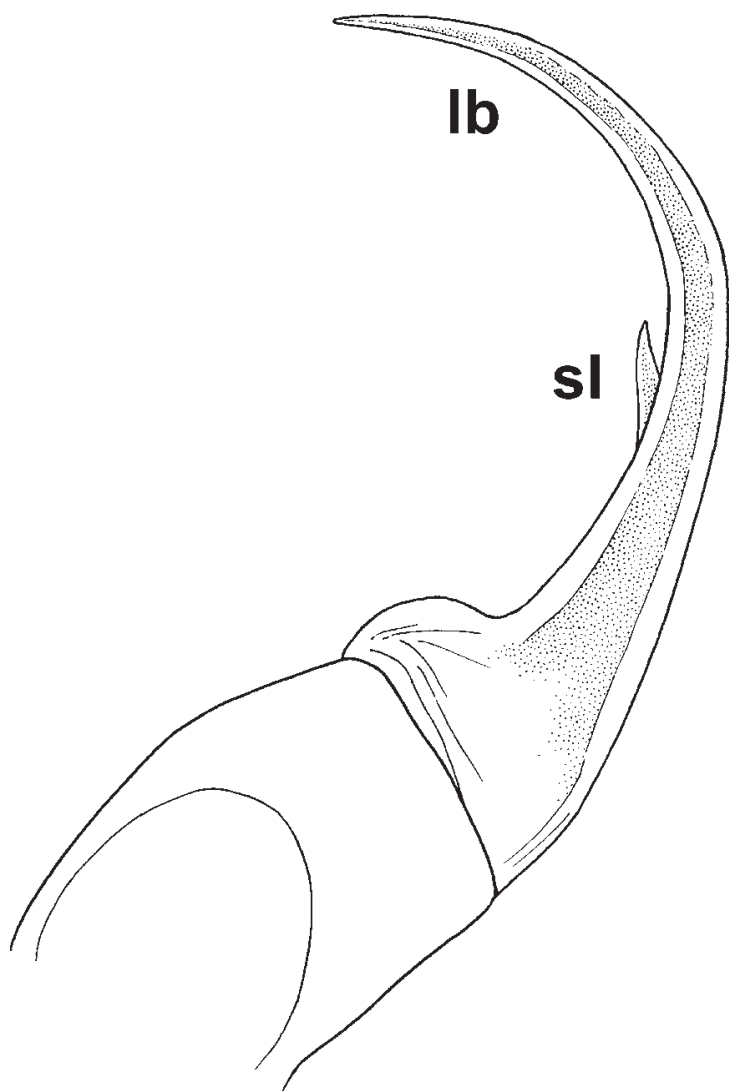

Fig. 101. Right posterior gonopod of Salpidobolus alokistus (Attems, 1914), $\sigma^{\top}$ near-topotype from Port Lae, anterior view. Designations explained in text. Drawn not to scale.

Рис. 101. Правый задний гонопод Salpidobolus alokistus (Attems, 1914), О7 почти топотип из порта Lae, спереди. Объяснения обозначений в тексте. Нарисовано без масштаба.

All characters as in Propodobolus sp., except as follows.

Tegument smooth and shining, mostly very delicately vermiculate. Antennae with numerous, small, apical cones; antennomeres $5-7$ densely setose, $4^{\text {th }}$ with several setae only near apical end; in length, $2>3>4=5=6>1>7$. Interantennal isthmus ca. $3 x$ diameter of antennal socket. Collum broadly and regularly rounded laterally, only anterolateral margin rather briefly, narrowly and faintly bordered, but caudolateral corner clearly swollen, drop-shaped and rounded. Midbody segments/rings faintly striate to striolate, more densely and clearly so ventrad, striations often being irregular, on dorsum above ozopore level strongly obliterate, represented by faint, low, longitudinal ribs only on metazonae (Fig. 95). Scobinae absent. Ozopores small, inconspicuous disks, starting with ring 6 , each pore lying upon line/suture both just before metazona and longitudinal line. Numerous light and irregular spots/sigilla on internal surface of mesoand metazonae. Epiproct flattened dorsoventrally, in lateral view faintly concave at base of a short, but clear apical process. Paraprocts very clearly concave at ca. $1 / 3$ before caudal margin (Fig. 96).

Legs ca. $1 / 2$ as long as body height $\left(\sigma^{7}\right)$; sole pads absent. $\sigma^{\top}$ coxae 3-5 swollen ventrally (Fig. 94), a spine each above and below claw.

Gonopods (Figs 97-101). Anterior gonopods with a strong, very long/high, unusually slender, central, apically 
narrowly rounded, sternal process (s), the latter being much longer/higher than both coxa (cx) and telopodite (t) with its small, apical, rounded, caudolateral process (tp); cx stout, on each side with a moderate, elongate, mesal, rounded projection ( $\mathbf{m p}), \mathbf{t}$ much more slender than $\mathbf{c x}$. Telopodite of posterior gonopods consisting of an unusually short and peg-shaped solenomere (sl), and a much longer, regularly curved, apicolateral branch (lb) (Fig. 101).

REMARKS. The above sample fits very well the original description [Attems, 1914], including such particular characters as the presence of a short, but distinct, apical epiproct process, the shape of the anterior gonopods, and the unusually short and peg-shaped solenomere of the posterior gonopod.

Two syntypes of $S$. alokistus are housed in the Berlin Museum, both stated to be +9 [Moritz, Fischer, 1975], although Attems [1914] based his original description on a $O^{7}$ and a $q$ syntype. The Vienna Museum keeps only a micro preparation (NHMW 4029) containing several $\sigma^{T}$ legs, but no gonopods. Because the slide is labeled "Rhinocricus alokistus / Bukaua / ö. n. guinea", the specimen may well be presumed to represent a syntype. Since the above type locality lies just within the settlement of Lae, the new sample may be regarded as a near-typotype.

\section{Conclusion}

We hope the present paper will stimulate revisionary work on the numerous enigmatic or still poorlyknown types kept at various museums worldwide. Only a careful and meticulous approach can be recommended, especially as regards iconography. Describing further new taxa without proper revision of old data and material is to be strongly discouraged. One of the due efforts is preferably to get the responsible collection keepers involved, as many places are presently supplied with high-quality photographic equipment to obtain good colour images. Molecular research may also join in to seriously assess phylogenetic relationships between the numerous taxa. Cryptic speciation has long been documented in Rhinocricidae, based on both morphological and molecular evidence [Bond, Sierwald, 2003]. Taxonomically, the Rhinocricidae is a real challenge not only because of its remarkable diversity, but also because the family is notable for its reductionist evolutionary trends making any phylogenetic analysis particularly difficult [Pitz, Sierwald, 2010]. Hemianamorphosis may also make things more complicated [Mauriès, 1980; Enghoff et al., 1993; Bond et al., 2003].

Acknowledgements. We are most grateful to Dmitry Telnov (Natural History Museum, London, UK) for his valuable donations of material to the ZMUM and the great help in correcting an advanced draft of the manuscript. Special thanks are also due to Jörg Spelda and Stefan Friedrich (both ZSM) for the help in providing information concerning the types of Eurhinocricus saipanus. Chen ChaoChun (Kaohsiung, Taiwan) kindly helped us read some labels from Japanese. Kirill V. Makarov (Moscow, Russia) very skillfully took and/or edited most of the colour pictures used in the present study. The first author was partly supported by the Presidium of the Russian Academy of Sciences, Programme No. 41 "Biodiversity of natural systems and biological resources of Russia".

\section{References}

Attems C. 1897. Myriopoden // Kükenthal W. (Hrsg.). Ergebnisse einer zoologischen Forschungsreise in der Molukken und Borneo, im Auftrage der Senckenbergischen naturforschenden Gesellschaft. Teil 2: Wissenschaftliche Reiseergebnisse. Bd.1. Abhandlungen der Senckenbergischen naturforschenden Gesellschaft. Bd.23. H.3. S.473-536.

Attems C. 1914. Die indo-australischen Myriopoden // Archiv für Naturgeschichte. Jg.80A. H.4. S.1-398.

Attems C. 1915. Myriopoden von Ceram und Waigeu gesammelt von L. F. de Beaufort i. J. 1909 // Bijdragen tot de Dierkunde. Deel 20. P.1-12.

Bond J.E., Sierwald P. 2002. Eurhinocricus rosenbergi, a new species of rhinocricid from the Caribbean island of Jamaica (Spirobolida: Rhinocricidae) // Proceedings of the Biological Society of Washington. Vol.115. No.3. P.670-675.

Bond J.E., Sierwald P. 2003. Molecular taxonomy of the Anadenobolus excisus (Diplopoda: Spirobolida: Rhinocricidae) species-group on the Caribbean island of Jamaica // Invertebrate Systematics. Vol.17. P.515-528.

Bond J.E., Beamer D.A., Hedin M.C., Sierwald P. 2003. Gradual evolution of male genitalia in a sibling species complex of millipedes (Diplopoda: Spirobolida: Rhinocricidae: Anadenobolus) // Invertebrate Systematics. Vol.17. P.711-717.

Brölemann H.W. 1913. The Myriapoda in the Australian Museum. Part ii - Diplopoda // Records of the Australian Museum. Vol.10. No.6. P.77-158.

Carl J. 1918. Miscellanées diplopodologiques // Revue suisse de Zoologie. T.26. Fasc.13. P.417-468.

Chamberlin R.V. 1920. The Myriopoda of the Australian Region // Bulletin of the Museum of Comparative Zoology at Harvard College. Vol.64. No.1. P.1-269.

Enghoff H., Dohle W., Blower J.G. 1993. Anamorphosis in millipedes (Diplopoda) - the present state of knowledge with some developmental and phylogenetic considerations // Biological Journal of the Linnean Society. Vol.109. P.103-234.

Golovatch S.I. 2014. On some new or poorly-known millipedes from Chile and Argentina (Diplopoda) // Russian Entomological Journal. Vol.23. No.4. P.249-281.

Golovatch S.I., Mauriès J.-P., Akkari N. 2020a. On the collections of Indo-Australian Spirobolida (Diplopoda) kept in the Zoological Museum of the Moscow State University, Russia. 1. A new species of Arisemolus Hoffman, 1980 from Papua New Guinea // Arthropoda Selecta. Vol.29. No.3. P.309-315.

Golovatch S.I., Mauriès J.-P., Akkari N. 2020b. On the collections of Indo-Australian Spirobolida (Diplopoda) kept in the Zoological Museum of the Moscow State University, Russia. 2. Two new species of Spirobolellus Pocock, 1894 from islands off Papua New Guinea and Australia // Arthropoda Selecta. Vol.29. No.4. P.399-407.

González-Sponga M.A. 2005. Myriápodos de Venezuela. Diez nuevas species del género Rhinocricus (Spirobolida: Rhinocricidae) // Revista de Investigación. No.57. P.13-48.

Hoffman R.L. 1955. Studies on spirobolid millipeds. II. A second paper on the genus Eurhinocricus // Proceedings of the Biological Society of Washington. Vol.68. P.31-36.

Hoffman R.L. 1974. Studies on spirobolid millipeds. X. Commentary on the status of Salpidobolus and some related rhinocricid genera // Revue suisse de Zoologie. T.81. Fasc.1. P.189-203.

Jeekel C.A.W. 2001. A bibliographic catalogue of the Spirobolida of the Oriental and Australian regions (Diplopoda) // Myriapod Memoranda. Vol.4. P.5-104.

Mauriès J.-P. 1980. Diplopodes Chilognathes de la Guadeloupe et ses dépendances // Bulletin du Muséum national d'Histoire naturelle, Paris. Série 4. T.2, section A. No.4. P.1059-1111. 
Marek P.E., Bond J.E., Sierwald P. 2003. Rhinocricidae systematics II. A species catalog of the Rhinocricidae (Diplopoda: Spirobolida) with synonymies // Zootaxa. Vol.308. P.1-108.

Minelli A. (ed.). 2015. Treatise on Zoology - Anatomy, Taxonomy, Biology. Vol.2. The Myriapoda. Brill: Leiden - Boston. 482 pp.

Pitz K.E., Sierwald P. 2010. Phylogeny of the millipede order Spirobolida (Arthropoda: Diplopoda: Helminthomorpha) // Cladistics. Vol.26. No.5. P.497-525.

Rodrigues P.E.S., Ott R., Rodrigues E.N.L. 2012. New species and new records of millipedes of the genus Rhinocricus Karsch, 1881 (Spirobolida: Rhinocricidae) from southern Brazil // Zootaxa. Vol.3172. P.55-64.

Rodrigues P.E.S., Campos L.A., Ott R., Rodrigues E.N.L. 2020. Phylogeny of three species groups of Rhinocricus Karsch, 1881 based on morphological characters (Diplopoda, Spirobolida, Rhinocricidae) // Organisms Diversity \& Evolution. Vol.20. P.141-153.

Shelley R.M. 2014. A consolidated account of the polymorphic Caribbean milliped, Anadenobolus monilicornis (Porat, 1876) (Spirobolida: Rhinocricidae), with illustrations of the holotype // Insecta Mundi. No.0378. P.1-12.

Takakuwa Y. 1942. Myriapoda of the Micronesia // Kagaku-Nanyo (= Micronesian Science). Vol.5. No.1. P.14-44 [In Japanese and German].

Verhoeff K.W. 1937. Zur Kenntnis der Rhinocricidae // Zoologischer Anzeiger. Bd.118. H.3/4. S.90-102.

Responsible editor K.G. Mikhailov 